\title{
和時計から日本の歯車の源流を探る
}

\author{
上田 昭夫 ${ }^{* 1}$, 渡邊 淳 ${ }^{* 2}$, 宮㟝 美弥子 ${ }^{* 2}$, 久保 愛三*3, 松岡 裕明 $^{* 4}$
}

\section{Explores for the source of the gears in traditional Japanese clock (Wadokei)}

\author{
Akio UEDA ${ }^{* 1}$, Jun WATANABE ${ }^{* 2}$, Miyako MIYAZAKI ${ }^{* 2}$, Aizoh KUBO $^{* 3}$ and Hiroaki MATSUOKA ${ }^{* 4}$ \\ ${ }^{*}$ AMTEC INC. \\ 2510 Bay Tower 1-2-1 Benten, Minato-ku, Osaka 552-0007, Japan \\ ${ }^{* 2}$ THE SEIKO MUSEUM \\ 3-9-7 Higashi-Mukoujima, Sumida-ku, Tokyo 131-0032, Japan \\ ${ }^{* 3, * 4}$ Research Institute for Applied Sciences \\ 49 Ooicho, Tanaka, Sakyouku, Kyoto 606-8202, Japan
}

Received: 1 July 2016; Revised: 30 August 2016; Accepted: 26 February 2017

\begin{abstract}
The purpose of this study is to understand the nature of one of the oldest gears used in traditional Japanese clock. Today's gear manufacturing technology in Japan came mostly from Europe and America, but we do not know exactly, when and how the gears were manufactured for the first time in Japan. It is interesting to search for this history. It is also exciting to study the tooth profile, precision and accuracy of the gears, and materials of the gears at that time. So far, there have been some studies performed for the mechanism of traditional Japanese clocks/watches, but not for gears. Fortunately we have a chance this time to investigate gears for Japanese watch drive that was made in 1688. Tooth profile and pitch error were measured, and transmission error analysis was also performed. It revealed that the precision of the watch was extremely high without any rust for more than 300 years, even though they were all handmade by Japanese mechanism technician named Sukeza-emon Tsuda the III. In the old days, there was no study on conjugate tooth profile theory available, but mysteriously, tooth profile was nearly made in the form of cycloid. Moreover, the gear material investigation was very interesting: The texture of the gear material was very homogeneous and grain size is far smaller than that of today's comparable steel kind. Impurities in it were very small and scattered well in the matrix. The steel was surely made by Japanese sword smith. The ore of the steel was perhaps sand-iron and it was refined with pine charcoal. The steel was forged and forged by hand very hardly. As the result the quality of the steel of 1688 looks far better than today's industrial steel. This research enabled us to discover how Japanese gear technology was born and developed.
\end{abstract}

Key words : Gear, Clock, Tooth profile, Involute, Cycloid, Transmission error, Steel, Mechanism

\section{1. 緒 言}

今，我々が取り扱っている歯車は，欧米からの技術導入により成し得たものであるが，日本で最初に機器に使 った歯車はいつの頃であろうかという思いがある。その歯車とはどのような歯形であったのか，また，その精度 や材質について非常に興味のあるところである．誰しもが，機器に使われた歯車として最初に思い浮か心゙るのは 時計であろう。日本最初の機械式時計の技術は，キリスト教宣教師によって慶長 6 年 (1600 年)，天草島志岐の セミナリヨ（Seminario）付属の実業学校で印刷技術やオルガン，天文機器などと共に教育を受けたのが最初であ る. 時計作りにおいては，1601 年に有馬のセミナリヨ，長崎のコレジオ（Collegio）で日本の鍛冶たちがキリス

No.16-00295 [DOI:10.1299/transjsme.16-00295], J-STAGE Advance Publication date: 7 March, 2017

*1 正員，フェロー，アムテック（有）（†552-0007 大阪府大阪市港区弁天 1-2-1 ベイタワー2510）

*2 セイコーミュージアム（†131-0032 東京都墨田区東向島 3-9-7）

*3 正員, 名誉員，フェロー，（公財）応用科学研究所（干606-8402 京都府京都市左京区田中大堰町 49）

*4 (公財) 応用科学研究所

E-mail of corresponding author: ueda@amtecinc.co.jp 
Ueda, Watanabe, Miyazaki, Kubo and Matsuoka, Transactions of the JSME (in Japanese), Vol.83, No.847 (2017)

卜教宣教師の指導の元，時計を製作したのが日本の機械時計の始まりとされている（Shiling,1943）.

今まで和時計の構造についての研究（佐々木，近藤，2010）はなされているが，和時計に使われている歯車に ついての調查は歯車の大きさや歯数程度であり歯形論や歯車のかみ合い性能についての研究はなされていない. そこで本報では，これらの古い歯車を探求するため貞享 5 年（1688 年）に製作された和時計用に用いられている 歯車の形状精度や回転性能, 材料組織を評価した。調査の結果, 当時の時計歯車の品質や性能が明らかとなり, 製作技術の高さを推し量ることができた.

\section{2. 和時計}

和時計とは，江戸時代に日本で作られた機械時計であり，西洋から伝来した機械時計を基に，鎖国の状況下で 時計師たちが当時の日本の時刻制度, 生活様式にあうように考案, 改造した日本独特の時計である (相賀, 1988)。

日本人が時計なるものを始めて見たのは，種子島に漂着したポルトガル人が所有していたものであろうと推定 される. 日本に最初に来た時計の実物は残っていないが文献にはある.フランシスコ・ザビエル (Francisco de Xavier) が周防（山口）の国の守護大名, 大内義隆に贈呈した自鳴鐘で天文 20 年（1551 年）のことである（塙，1819）.

ここで代表的な当時の時計の例を示寸. 図 1 は, 我が国に現存する最も古い機械式時計（家康公の洋時計, 久 能山東照宮博物館所蔵) であり, 慶長 16 年 (1611 年), スペイン国王フェリペ (Felipe) 3 世から徳川家康に贈ら れたものである. 現在, 静岡県久能山東照宮にある宝物（重要文化財）として保存されている. この時計は, ぜ んまい駆動の鉄製機械で 1581 年スペイン国マドリッドにおいて Hans de Evalo 製作と彫刻されている.これは, 江戸初期（1608～1629 年）の外交資料である異国日記（崇伝筆）に慶長 17 年 7 月ノビスパン（Nueva Espana，メ キシコ）副王から使節が来朝したときの到来目録中に斗景 1 個とあるのに符合する．ただし，この時計の製作年 は 2014 年の静岡大学で行った X 線撮影によって 1573 年であることが判明した (Hoeve and Thompson, 2014).

図 2 は, 初代御幡儀右衛門茂矩（1802 年作）の銀側透かし彫り懐中時計（近藤勝之氏所蔵）である. 図 3 は弘 化 4 年（1847 年）, 田中久重作（機械）, 松本喜三郎作（外装）の須弥山儀（天象機の一種, 総高さ $470 \mathrm{~mm}$, 盤 上円直径 $330 \mathrm{~mm}$,「時計の大橋」蔵, セイコーミュージアム展示）であり，胴体中央部に和時計がある．また， 図 4 の浮世絵（国立東京博物館所蔵, 西川祐信[1671-1750]作）には一挺天符の和時計が描かれており当時の様子 を窥い知ることができる.

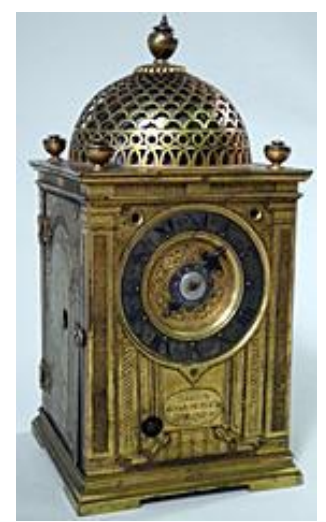

Nicolavs de Troestenbergh (1573), Spain

$\mathrm{T}=\mathrm{W}=105, \mathrm{H}=215$

Fig.1 Ieyasu's clock.

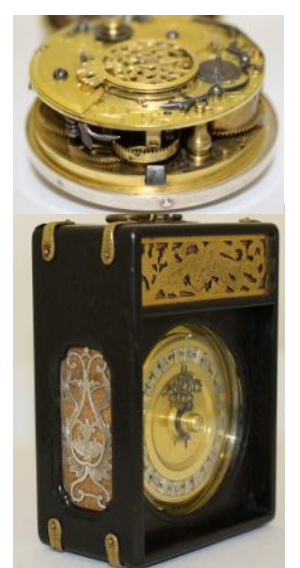

Shigenori (1802), Japan $\mathrm{T}=47, \mathrm{~W}=83, \mathrm{H}=110$

Fig.2 Watch.

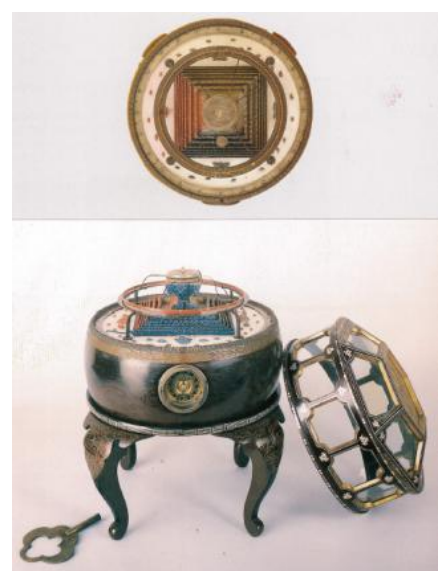

Giemon TANAKA and Kisaburo MATSUMOTO, (1847), $\mathrm{D}=330, \mathrm{H}=470$ Fig.3 Shumisen-gi.

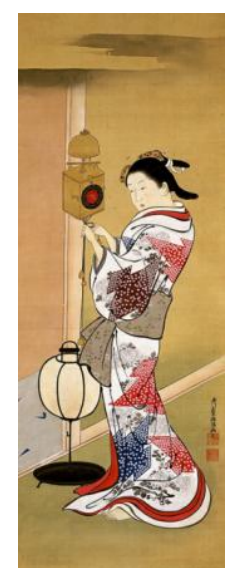

Sukenobu NISHIKAWA (1671-1750), $883 \times 314 \mathrm{~mm}$

Fig.4 Picture (Ukiyo-e).

秀吉, 家康の時代には相当数の舶来時計が当時の権勢ある人々に賞玩されていたようである. これらの時計の あるものは故障を起こし修理を要することになるのは必然で，ここに日本人による時計師なるものが生まれた. そして，やがて日本人による時計ができ，時計用の歯車が日本人によって製作されることになる.

和時計の製作地としては, 長崎を筆頭に松江, 京都, 大阪, 堺, 伊勢, 名古屋, 若狭, 江戸, 仙台, 盛岡, 弘 前などが挙げられる，これらの土地は海外との交涉の多いところ，文化の中心地，鍛冶金工の盛んなところ，ま た，時計に関心を持つ大名のいたところである．寛政（1789～1801 年）から文化（1804～1818 年）・文政（1818 
$\sim 1830$ 年）の頃は，和時計の製作技術も高潮に達し，さらに天保（1830～1844 年)，弘化（1844～1848 年)，嘉 永（1848～1854 年）と続くこの時代は量，質ともに和時計の全盛期となった. 江戸時代の時刻制度は，不定時法 が採用され 1 日の長さを等分するのではなく, 昼と夜それぞれを等分する. 寸なわち, 季節によって昼と夜の長 さが異なることから分割した単位時間の長さも変化することになる．江戸時代の四季の時刻と現代の時刻を図 5 に示す (小田, 1994).

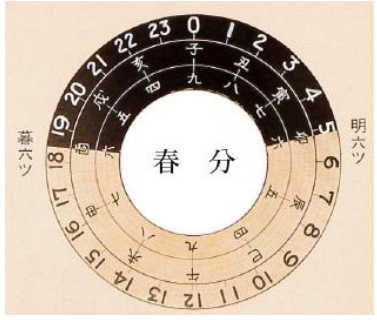

(a) Spring equinox

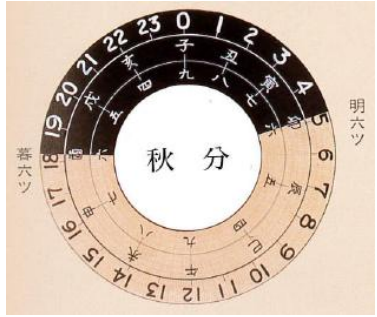

(b) Autumnal equinox

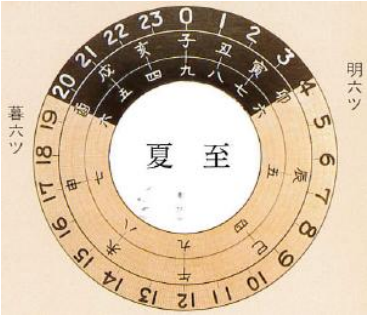

(c) Summer solstice

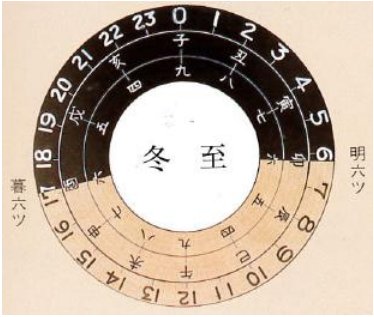

(d) Winter solstice

Fig.5 Time of the four seasons of the Edo period and the time of today. It adjusts time of the noon and night by the watch mechanism (ODA, 1994).

不定時法を時計に反映させるために基本的には二通りの方法がある. ひとつは, 機械の運転速度を必要に応じ て変える方法であり，いまひとつは，運転速度は一定にしておき文字盤の時刻目盛を可変または交換して不定時 法時刻を知る方法である，棒天符は，左右の分銅の位置を遠ざければ遅く，近づければ早く振れることで運動速 度を変えることができる．図 6(a)の一挺天符では毎日 1 日に 2 回，明け六つと暮れ六つに分銅を掛け替えなけれ ばならない．この手間を省くため工夫されたのが二挺天符である。この機構は図 6(b)のように昼間用と夜間用に 二本の棒天符を取り付け，明け六つと暮れ六つに自動的に切り替わる仕組みである．天符の分銅は節気ごと，つ まり半月ごとに移動させておけば良い。この画期的な考案が，いつ，誰によるものであるかは解っていない（小 谷, 2010)。この機構は 17 世紀半ばに現れ，不定時法に対応するための基本機構として和時計に取り入れられて いった. 江戸後期になると, 調速機に使われたのは, ひげゼンマイ円天符が多く, 振り子は江戸末期で少数派で あった. 図 6(c)は，振り子時計の調速脱進機の構成図であるが，この機構にフェースギヤが使われていることが 興味深く，ひげ円天符および振り子は，棒天符の疑似周期制御ではなく周期制御のため一定の速さで時を刻む時 計としての精度向上に貢献したと思われる. 割駒式文字盤（印籠時計，枕時計など）, 節板式文字盤と波板式文字 盤（尺時計）は，時刻調整でなく不定時法時刻表示のための可変，交換，グラフ式などの文字盤のバリエーショ ンである.このようにして不定時法に対応した機構が開発されたが，明治 5 年（1872 年）の改暦により日本も欧 米と同じく太陽暦による定時法 (1 日 24 時間)が採用されるに至り和時計は急速に廃れてしまった(小田, 1994).

定時法時計が伝来し，これを我が国独特の不定時法に合わせて時計を作り 200 年ほど経て再び定時用法に戻す 結果になったが，培われた技術は日本の時計史上に貴重な一頁を残すことになった。また，この技術は，日本の 産業技術の発展に役立ったことは想像に難くない.

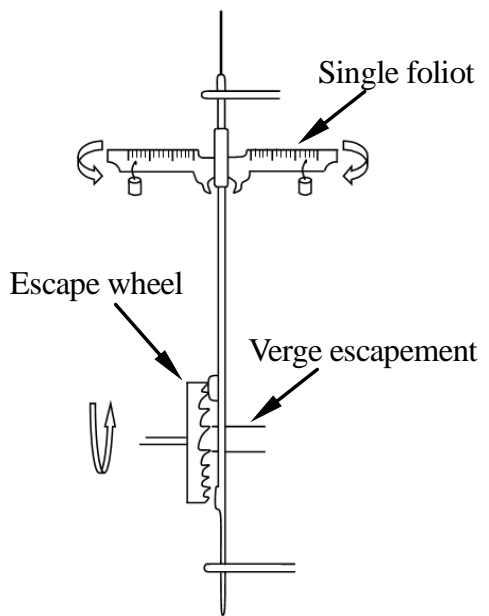

(a) Single foliot type

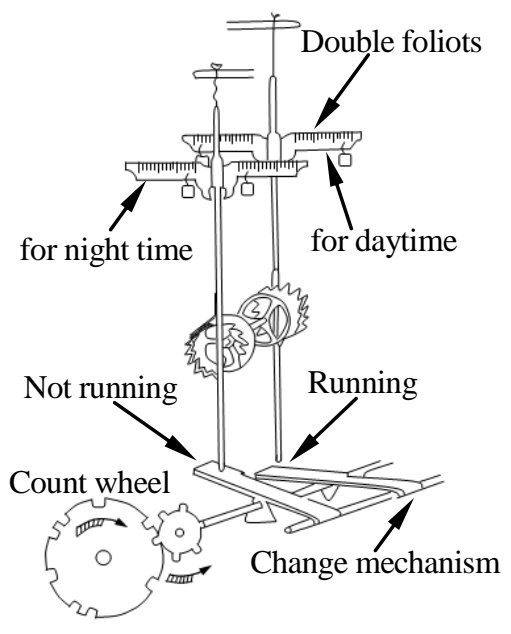

(b) Double foliots type

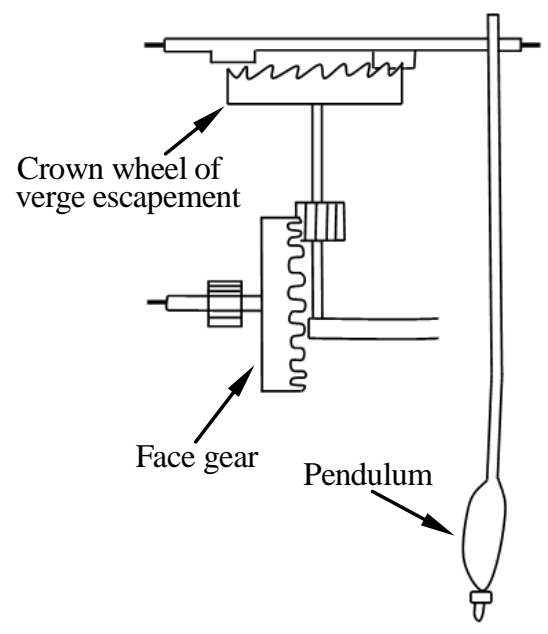

(c) Pendulum type

Fig.6 Mechanism of the traditional Japanese clock (Wadokei), (ODA, 1994). 


\section{3. 調查対象の和時計}

本論は和時計に使用されている歯車について検討・調査するものである．対象とする和時計は，セイコーミュ ージアムが所蔵する三代目津田助左衛門信貫が貞享五年（1688 年）に製作した二挺天符櫓時計である. 初代助左 衛門は和時計製作の元祖とされており初代から 10 代良晃まで続いている（佐々木，近藤，2010）。初代津田助左 衛門の生没年について，名古屋千草にある墓誌には没年「嘉永十五年十二月廿五日」（1638 年）とあるが，一般 的には不明とされている. また，津田が日本初（1598 年）の時計製作者との説が一般的であるが，最近の研究で は，その説の前提となっている「尾張記・津田家の由緒書」の記述が確かではなく，津田助左衛門が初めて製作 した年代は元和九年 (1623 年) で, 深田円空が設計し, 尾張藩主に献上した「おもり時計（正室時計）, 1623 年」 が最初とする説が有力である（河本，2013）.

三代目津田助左衛門信貫が製作した和時計（1688 年 12 月）を図 7 に示寸. 図 7(b)の写真から和時計の構造が 良く解り, 図 7(c)の底板下面には「貞享五年辰ノ十二月（1688 年)」の文字が彫られている. 本論で検討寸る歯 車は，図 7(d) (e)のように和時計を分解し取り出した歯車（P1, G1, P2, G2）とする.

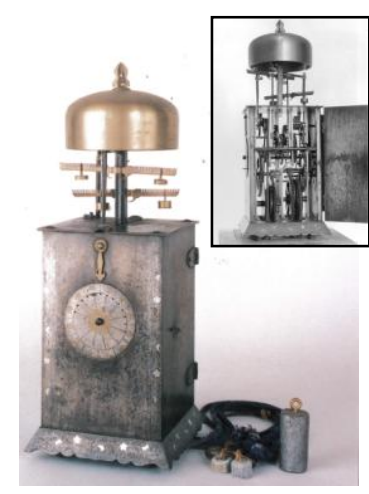

(a) Appearance $\mathrm{T}=\mathrm{W}=115$

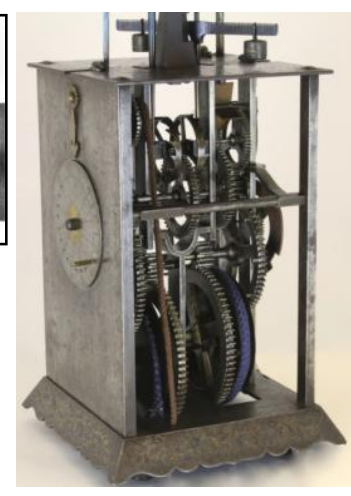

(b) Innards

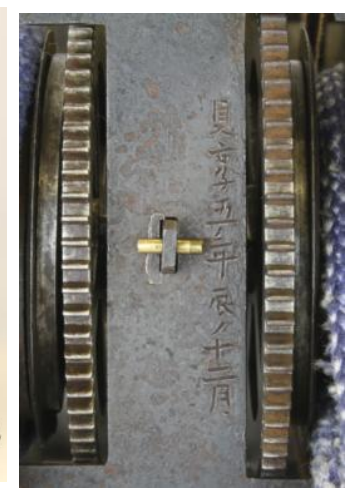

(c) Plate of the author

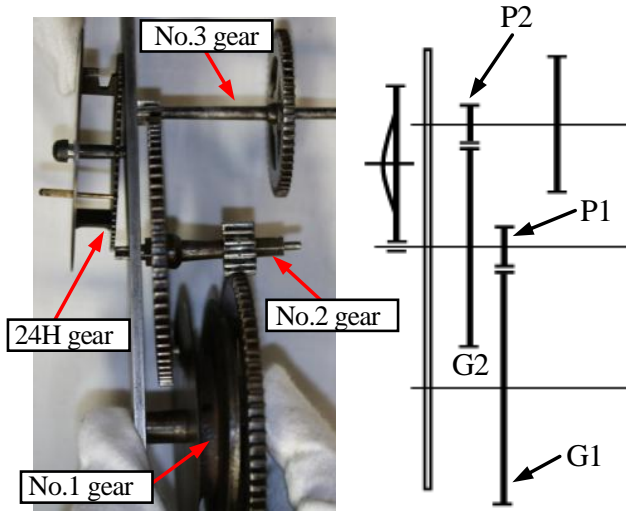

(d) Gear sets

(e) Gear train

Fig.7 Traditional Japanese clock (double swing bar type), (1688), made by 3rd Sukezaemon TSUDA.

\section{$4 \cdot 1$ 検討する歯車}

\section{4. 和時計歯車の測定}

図 7 の和時計を分解し取り出し調査した歯車の写真を図 8〜図 10 に示寸. 写真を見るとこれらの歯車は 328 年 を経ているが全く錆びていない，これは，防錆技術として熱した鉄に漆を焼き付ける工法を採用していること， また，管理の方法にもよるだろうが，材料そのものが良質であると推測することができる. 本論で対象とする歯 車は, 図 8(a)の 1 番車 $(z=72)$ と(c)の 2 番車の小歯車 $(z=13)$ の歯車対, そして, 図 8(c) の 2 番車の大歯車 $(z=72)$ と図 9(d)の 3 番車の小歯車 $(z=6)$ の歯車対である. ただし, 図 9(c) の 3 番車の大歯車は, かみ合う相手歯車が無 いことから今回の検討には含めない. また, 図 9(b)のピン歯車 $(z=3)$ とかみ合う図 10(a)の 24 時車（z=72）も今 回のかみ合い検討には含めない. また，図 10(b)に軸受板を示すが，軸受穴部には銅系のブッシュが丁寧に挿入さ れていることが解る. 歯車および軸受板の概略図を図 11〜14に示す.

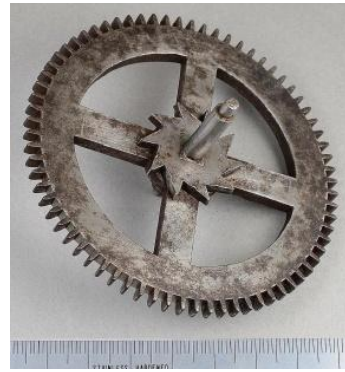

(a) No.1 gear

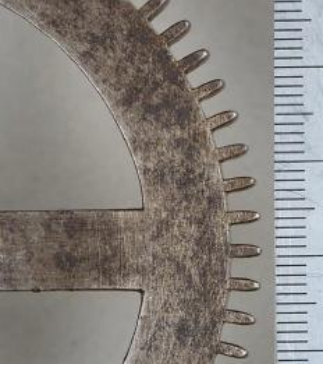

(b) Tooth profile of No.1 gear

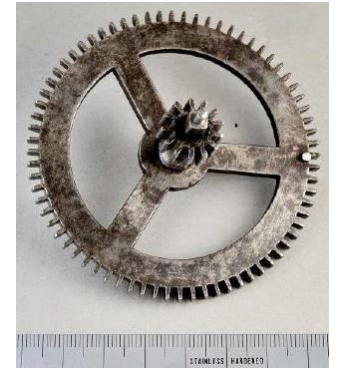

(c) No.2 gear

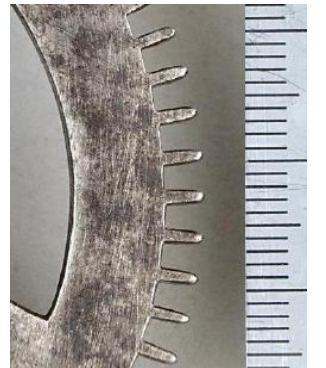

(d) Tooth profile of No.2 gear

Fig.8 Traditional clock's gears(No.1 No.2). 


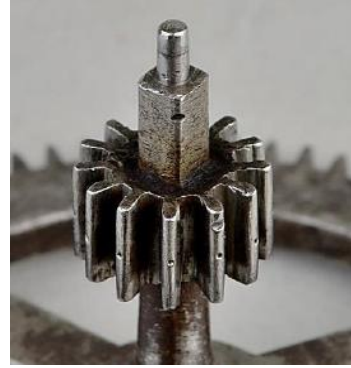

(a) No.2 gear/pinion

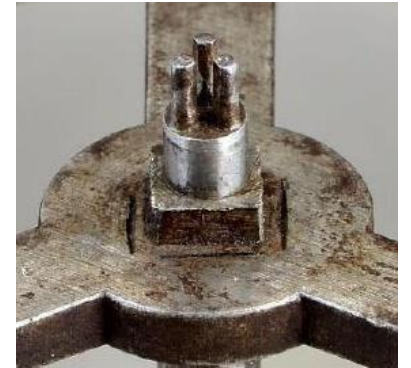

(b) No.2 gear/pin pinion

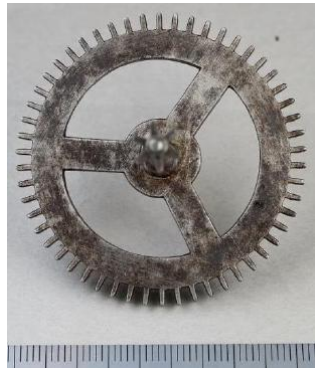

(c) No.3 gear

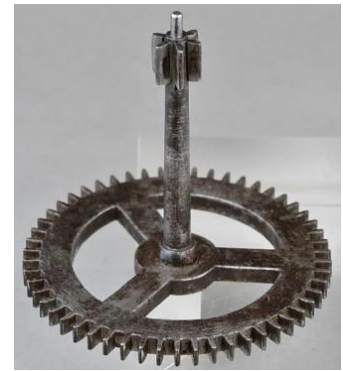

(d) No.3 gear/ pinion

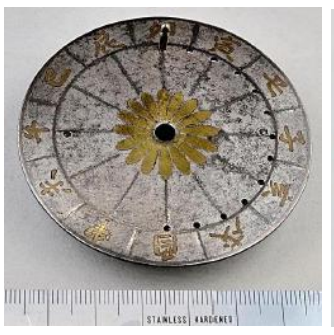

(a) $24 \mathrm{H}$ gear (pin gear)

Fig.9 Traditional clock's gears(No.2 No.3).

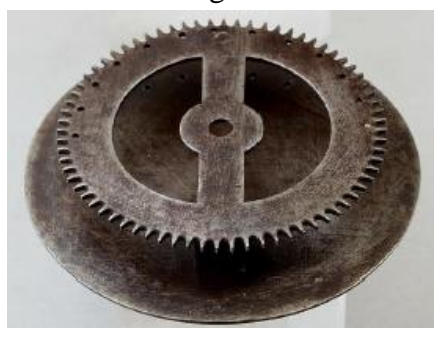

Fig.10 Traditional clock's $24 \mathrm{H}$ gear and the plate type bearing

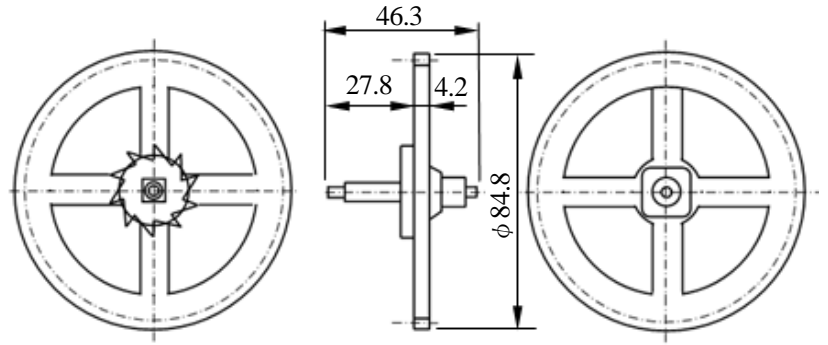

Fig.11 No.1 gear.

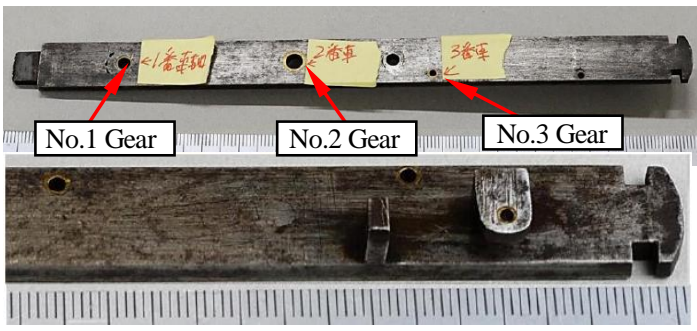

(b) plate / metal bearing

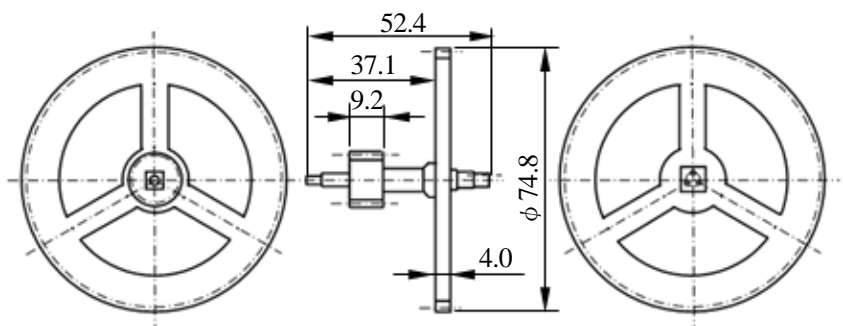

Fig.12 No.2 gear.

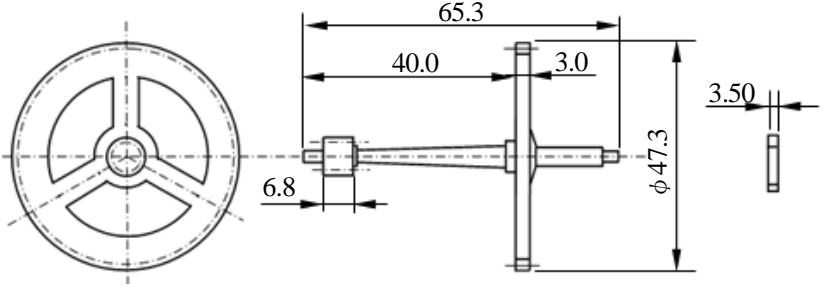

Fig.13 No.3 gear.

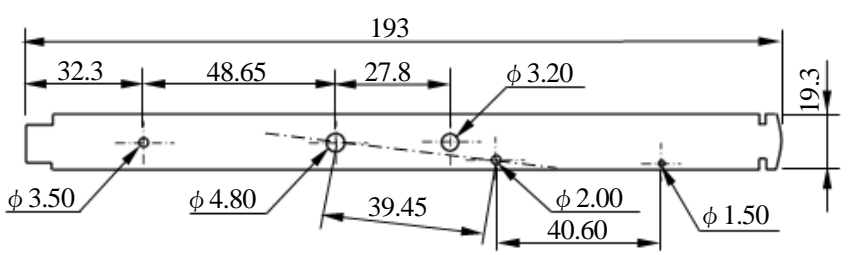

Fig.14 Plate / metal bearing.

\section{$4 \cdot 2$ 和時計歯車の歯形}

近年の時計歯車の歯形に数多く使用されているサイクロイド曲線は, ヨーロッパではレーマーが 1674 年に提唱 している. 歯形曲線について江戸時代に盛んであった和算について調査したところ図 15 のように岡山県吉備津神社に 藤田助次郎秀斎が奉納した算額（岡山県立博物館蔵）に幾何学ししてのサイクロイド曲線が示されている.これを 読み解いたのが図 16 に示寸社寺奉納算額集（清水，1942）である. しかし，今回調查した和時計の歯形は，サイ

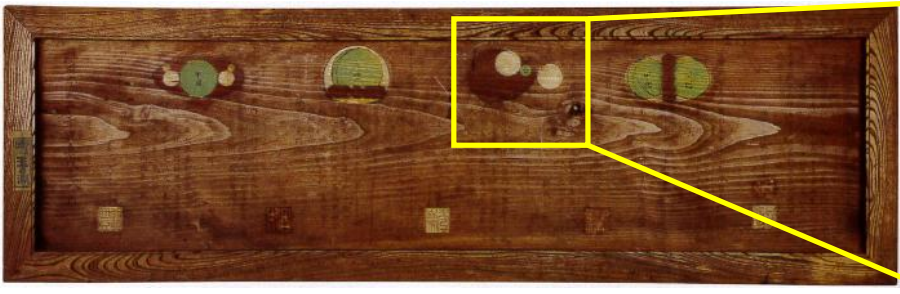

岡山県備中國吉備郡眞金村宮内，官幣中社吉備津神社，安政 5 年（1858 年）

Fig.15 "San Gaku" of the cycloid curve, Japanese traditional mathematical problem,(1858).

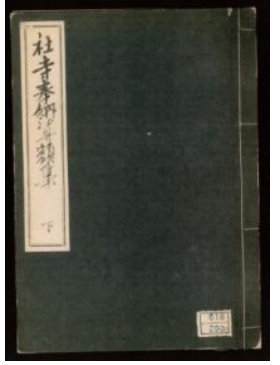

Fig16 "San Gaku" collection. 
クロイド歯形に近いものであったが, 和算をもとにして歯形理論が発達, もしくは取り入れられた形跡は文献上, 見出すことが出来なかった．なお，和算に関する書籍（深川，1995）には数多くの設問の中にインボリュートの 項があるが，ここには基準形状が多角形の展開線が示されている. しかし，現在，歯車の歯形として使われてい る基準形状が円であるインボリュート曲線は見出すことが出来なかった.

時計歯車の歯形写真（図 17 および図 18）は, サイクロイド歯形と推察することができるため歯先円直径, 歯 底円直径，歯先形状そして歯厚を時計歯車の歯形に近付けるようサイクロイド歯形理論に基づき設計した．その 歯形を図 19 および図 20 に示す. サイクロイド曲線に基づいて設計した歯車は, 表 1 の諸元を持ち，かみ合い率 も 1.0 以上を満足するため滑らかに回転する. しかし, 図 17 の歯車では, 小歯車を矢印方向に回転させたとき, 小歯車の 2 番歯と大歯車の 2 番歯は接触しているが，先行する 3 番歯同士は接触せず小歯車の 4 番歯と大歯車の 3 番歯の非作用面が接触している. そのため, かみ合い率は $\varepsilon<1.0$ である. また, 図 18 歯車のかみ合いでは小歯 車の 2 番歯と大歯車の 2 番歯は接触しているが，先行する 3 番歯同士は接触していない，そのため，この歯車対 も，か夕合い率は $\varepsilon<1.0$ である.

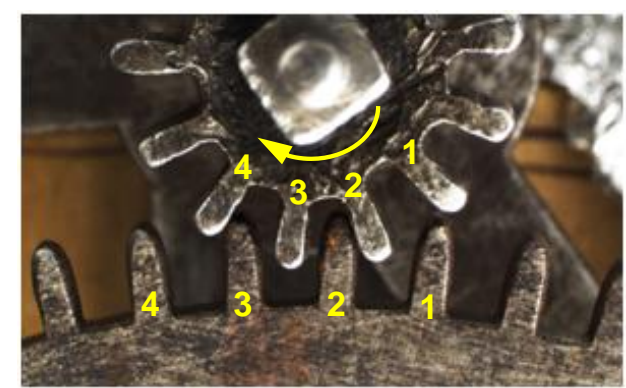

Fig.17 1st gear pair $\left(z_{1}=13, z_{2}=72\right)$.

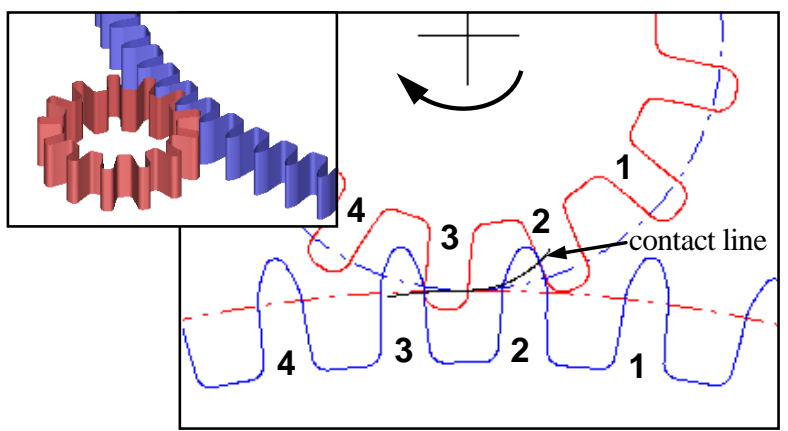

Fig.19 1st gear pair $\left(z_{1}=13, z_{2}=72\right)$, cycloid gear.

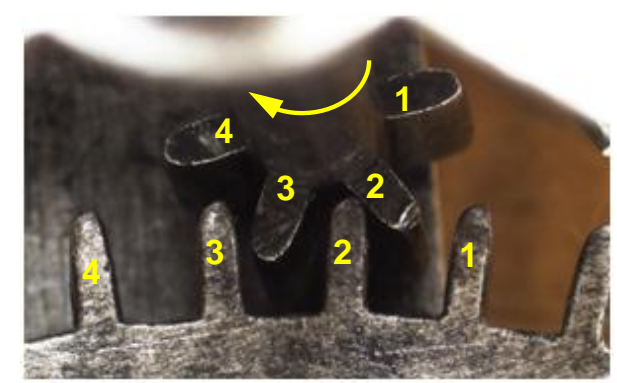

Fig.18 2nd gear pair $\left(z_{1}=6, z_{2}=72\right)$.

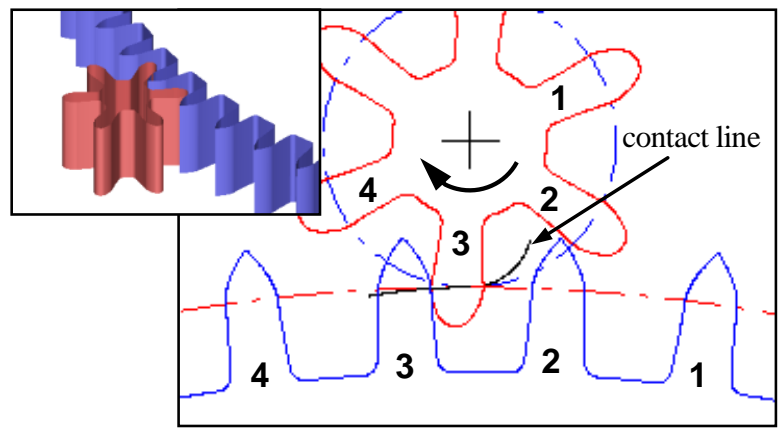

Fig.20 2nd gear pair $\left(z_{1}=6, z_{2}=72\right)$, cycloid gear.

Table 1 Cycloid gear dimensions.

\begin{tabular}{|l|c|cc|cc|}
\hline \multicolumn{1}{|c|}{ Item } & unit & \multicolumn{2}{|c|}{ 1st gear pair } & \multicolumn{2}{c|}{ 2nd gear pair } \\
\hline Gear type & ---- & pinion(P1) gear(G1) & pinion(P2) & gear(G2) \\
Module & $\mathrm{mm}$ & \multicolumn{2}{|c|}{1.142} & \multicolumn{2}{c|}{1.01} \\
Number of teeth & ---- & 13 & 62 & 72 \\
Reference diameter & $\mathrm{mm}$ & 14.846 & 82.224 & 6.060 & 72.720 \\
Epi-cycloid radius & $\mathrm{mm}$ & 14.846 & 3.000 & 12.000 & 1.280 \\
Hypo-cycloid radius & $\mathrm{mm}$ & 3.000 & 14.846 & 1.280 & 12.00 \\
Tip diameter & $\mathrm{mm}$ & 16.00 & 84.8 & 7.70 & 74.8 \\
Root diameter & $\mathrm{mm}$ & 10.00 & 78.0 & 3.40 & 69.2 \\
Tip radius & $\mathrm{mm}$ & 0.500 & 0.30 & 0.40 & 0.60 \\
Bottom radius & $\mathrm{mm}$ & 0.400 & 0.45 & 0.30 & 0.30 \\
Facewidth & $\mathrm{mm}$ & 9.2 & 4.2 & 6.80 & 3.5 \\
Center distance & $\mathrm{mm}$ & \multicolumn{2}{|c|}{48.535} & \multicolumn{2}{c}{39.390} \\
Contact ratio & ---- & 1.088 & \multicolumn{2}{c}{1.132} \\
Backlash & $\mathrm{mm}$ & \multicolumn{2}{|c}{1.00} & \multicolumn{2}{c}{} \\
\hline
\end{tabular}

\section{$4 \cdot 3$ 歯の外周振れ}

1 番車， 2 番車そして 3 番車の外周振れを計測した. 測定の様子を図 21 に示寸. これらの歯車は，3 種類共， 図 22 のように大歯車の四角形状穴に軸を挿入しているにも関わらず大歯車の外周振れは，図 23 のように $0.06 〜$ $0.11 \mathrm{~mm}$ である. 当時の道具を想像するとハンマ, タガネ, キリ, ヤスリ程度で作ったと思われるが, どのよう 
な方法で作り上げたのか非常に興味がある．汎用旋盤時代の旋盤師はトースカンのみで軸の振れを電球の明るさ を利用して $0.02 \mathrm{~mm}$ 程度に抑えていたが，これらの時計歯車も同様の作業をしていたものと推測している.

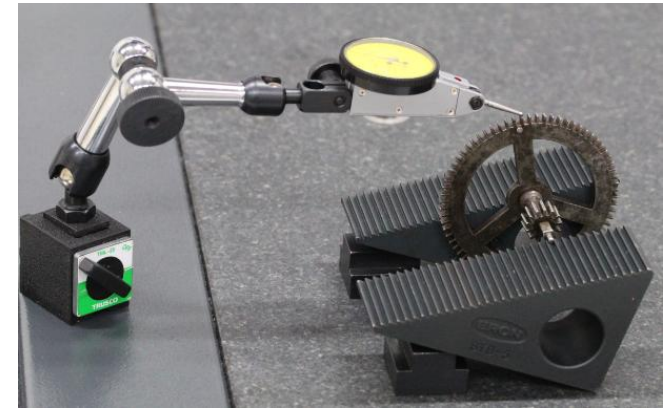

Fig.21 Measurement of outside run-out (No.2 gear).

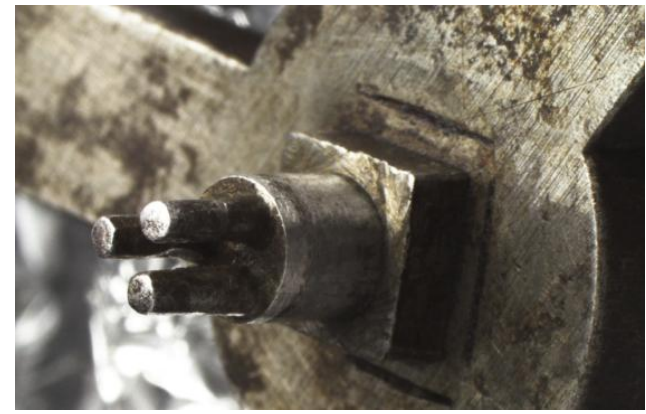

Fig.22 Joint of the gear and shaft (No.2 gear).

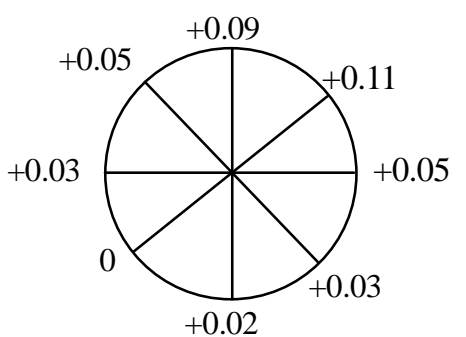

(a) No.1 gear $(z=72)$

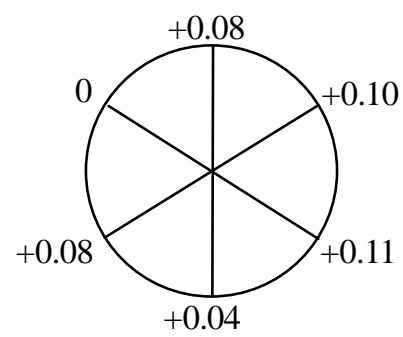

(b) No.2 gear $(z=72)$

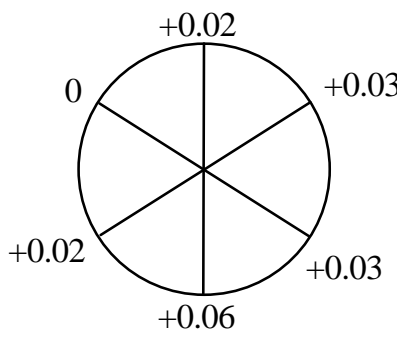

(c) No.3 gear $(z=72)$

Fig.23 Run-out on tip circle diameter (unit: $\mathrm{mm}$ ). Although a shaft is inserted into a square-shaped hole, the wheel runout is found to be only $0.06-0.11 \mathrm{~mm}$. The available tools were probably something like hammer, chisel, drill and file at the time of manufacturing, but it is surprising that this level of accuracy was achieved.

\section{4 - 4 歯形測定}

前節では，サイクロイド歯形と推測して歯のかみ合いを確認したが，高精度に測定できるサイクロイド歯形測 定機が無いため, 1 番車と 2 番車そして 3 番車の小歯車を図 24 のインボリュート歯車測定機（大阪精密機械製， CLP-35）で修整インボリュート歯形として測定した. 測定時の様子を図 25 に示寸. 測定項目は，歯形誤差，歯 すじ誤差およびピッチ誤差とし，歯形誤差および歯すじ誤差は歯車円周 4 等分の位置で計測した。ただし，24 時 車は歯車測定機では測定不可であるため実施していない，和時計歯車の歯形は，歯形理論が不明であることから 歯車の直径と歯数からモジュールを推測し, 測定可能となる圧力角を決定した. その結果, 1 番車の大歯車と対 をなす 2 番車の小歯車のモジュールは $m=1.142$, 圧力角は, $\alpha=18.5^{\circ}$ と決まる. また, 2 番車の大歯車と対をなす 3 番車の小歯車のモジュールは $m=1.01$, 圧力角は, $\alpha=0.98^{\circ}$ である. 測定結果を見ると, 例えば図 26 の 1 番車の 歯形誤差（理論インボリュート歯形との偏差）は $F_{\alpha}=309 \mu \mathrm{m}$ であるが， 4 等分個所の歯形は等しく作られている ことが解る. また, 左右歯面の形状が大きく違っていないことから摩耗による大きな歯形変化は認められない. また，歯すじ誤差は $F_{\beta}=25.4 \mu \mathrm{m}$ であるが，これはクラウニングを施しているためであり，その形状は非常に綺麗 に仕上がっている. 歯面の摩耗について見ると, 大歯車の摩耗は軽微であるが, 小歯車の図 29 の歯すじ誤差の検 查結果から歯幅中央部で $17.0 \mu \mathrm{m}$ 程度摩耗している. しかし, 反作用面の歯すじ形状は摩耗していないため大歯 車と同様に綺麗なクラウニングが施されたままの歯形が残っている. クラウニングを施している理由は, 機構の ゆがみを吸収するためであり, その配慮は, 板軸受の端部を固定しない構造にも表れている. この軸端を固定し ない構造は機械精度や経年変化を考慮しているものと推察することができる.

ピッチ誤差の測定結果を図 30〜33 に示す. 図 30 および図 32 の $z=72$ ではそれぞれ $f_{\mathrm{pl}}=104 \mu \mathrm{m}, f_{\mathrm{p}}=126 \mu \mathrm{m}$ であ るが, 図 33 の $z=6$ では $f_{\mathrm{pl}}=45.5 \mu \mathrm{m}$ と良好である. しかし, 図 31 の $z=13$ では歯数が素数であることから $f_{\mathrm{pl}}=336 \mu \mathrm{m}$ と極めて精度が悪い，歯を円周上に正しく削りだす方法は歯車の直径の数倍の円盤に分割目盛を与え，これを基 準として歯を分割すれば基準円盤と歯車の直径に比例して分割精度は良くなるが, $z=13$ の素数であるため基準円 盤も正確に分割することができなかったものと推測することができる. また, 図 25(d)のピニオン歯先に見える小 さなポンチ穴は歯数を分割するための目印と思われる. この時代の円周率は，村松茂清（1608～1695）が $2^{15}$ の 正多角形により円周率を小数点以下 7 桁まで計算（平山，1980）しているため 1688 年当時であれば歯車を製造す 
るための円周率の桁数は充分であった。 しかし，この時代の時計の製作技術では円周率の有効な活用がなされて いなかったものと思われる.

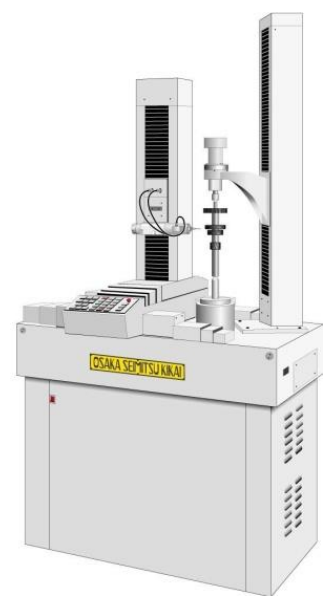

Fig.24 CNC Automatic gear measuring machine, CLP-35, Osaka Seimitsu Kikai.

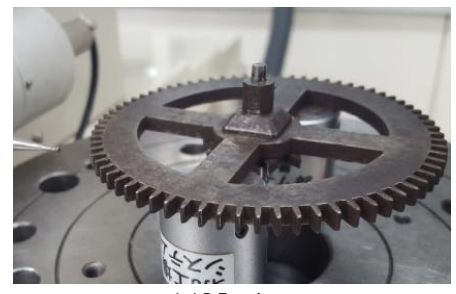

(a)No.1 gear

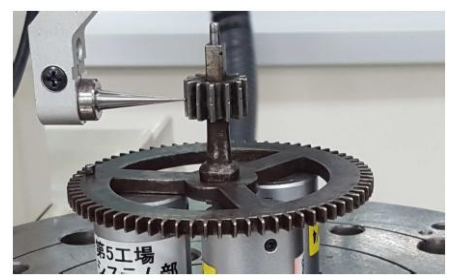

(c) No.2 gear

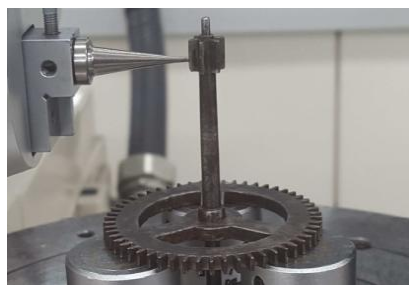

(b) No.3 gear/ pinion

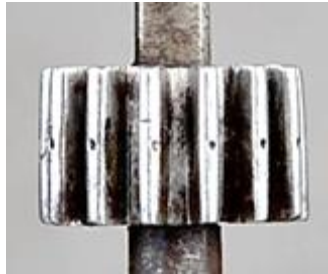

(d) No. 2 gear/pinion, $z=13$

Fig.25 Measurement of the gears.
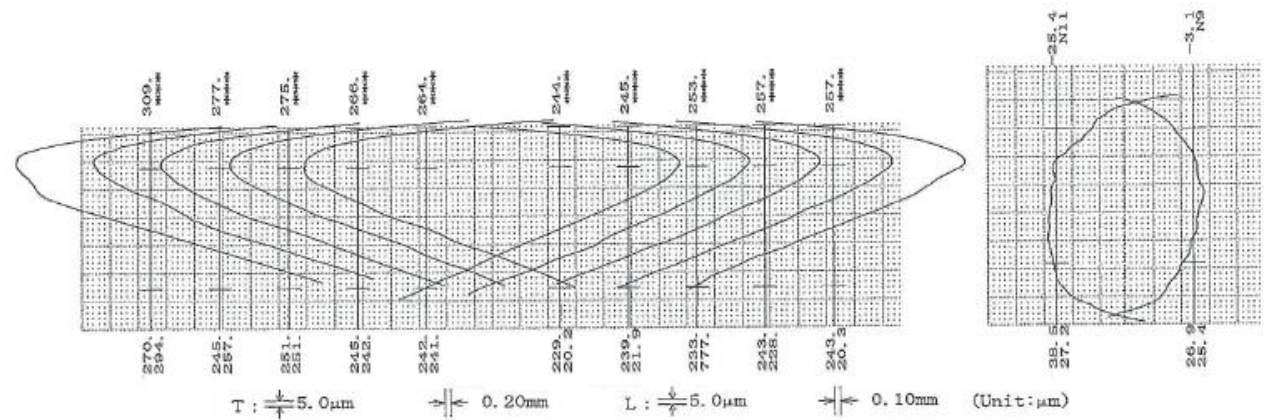

Tooth profile deviation, $F_{\alpha}=309$

Lead deviation, $F_{\beta}=25.4$

Fig.26 Gear measurement, No.1 gear, $\times 200, m=1.142, z=72, \alpha=18.5^{\circ}$, These gears are handmade. But, there are no major tooth profile changes by wear, as the tooth profile difference is minimal between left and right flanks.

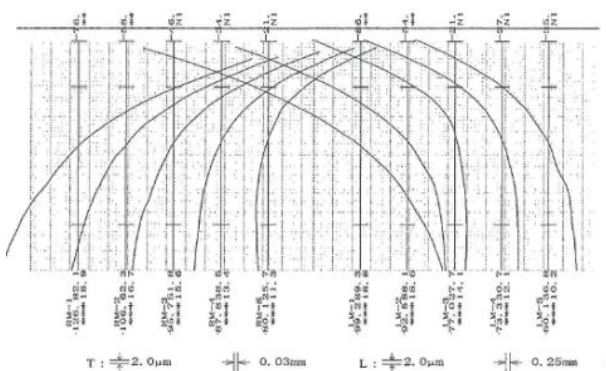

Tooth profile deviation $F_{\alpha}=76$

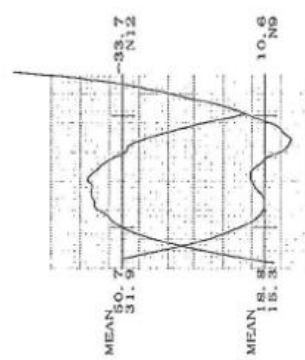

Lead deviation, $F_{\beta}=33.7$

Fig.27 Gear measurement, No.2 gear, $\times 200, m=1.142, z=13, \alpha=18.5^{\circ}$.

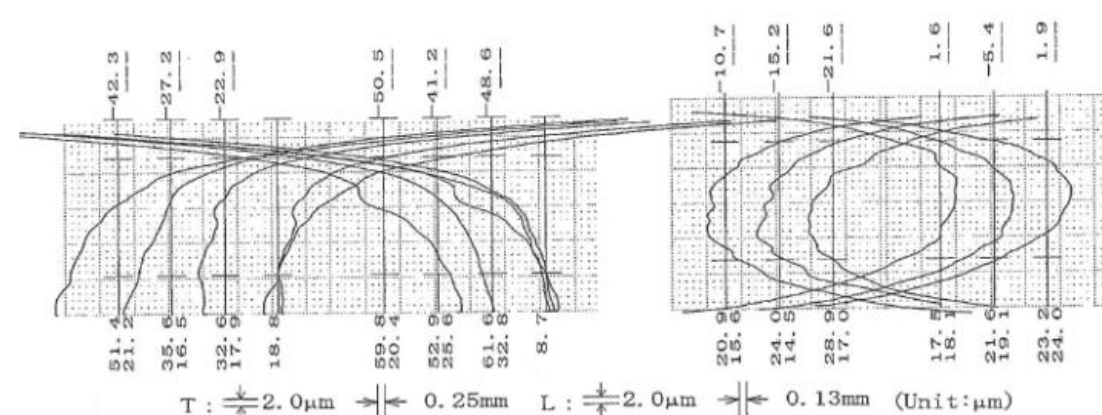

Tooth profile deviation, $F_{\alpha}=42.3$

Lead deviation, $F_{\beta}=10.7$

Fig. 28 No. 2 gear, $\times 500, m=1.01, z=72, \alpha=0.98^{\circ}$, The lead deviation is found to be $F \beta=25.4 \mu \mathrm{m}$, but it is caused by crowning. In fact, the crowning profile is very well made. 


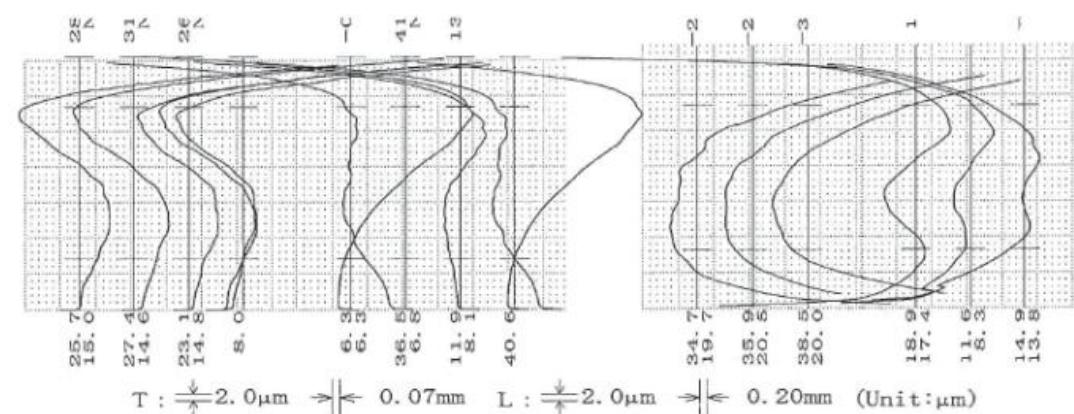

Tooth profile deviation, $F_{\alpha}=25.7$

Lead deviation, $F_{\beta}=34.7$

Fig.29 Gear measurement, No.3 gear, $\times 500, m=1.01, z=6, \alpha=0.98^{\circ}$

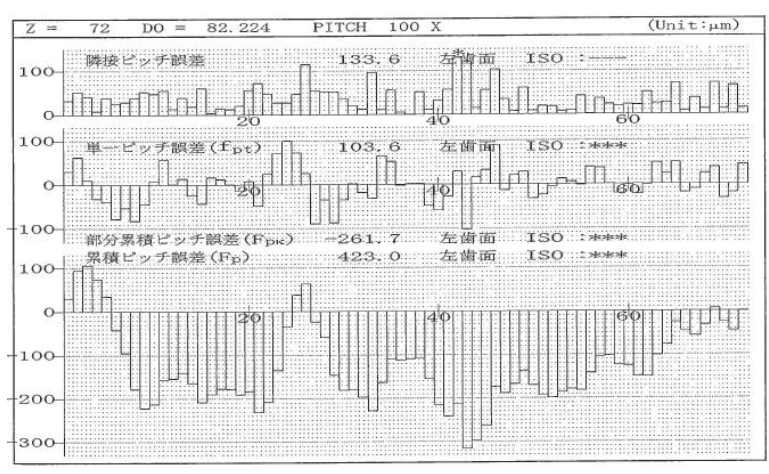

Pitch deviation, $f_{\mathrm{pt}}=104$

Fig.30 No.1 gear, $m=1.142, z=72, \alpha=18.5^{\circ}$.

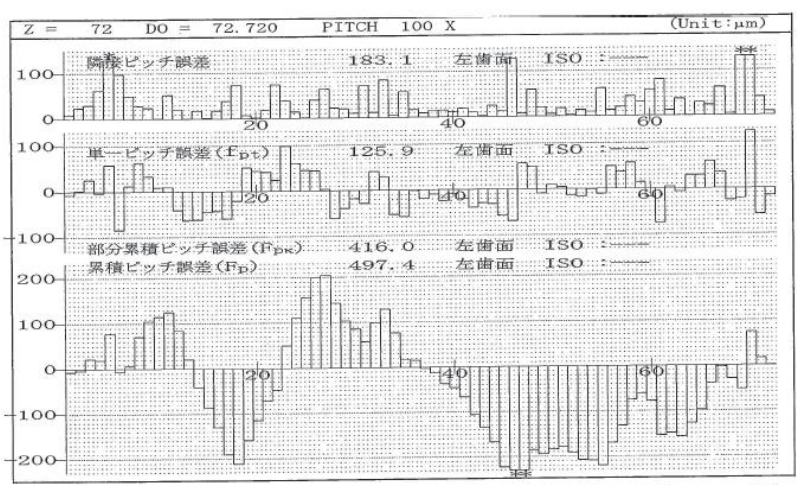

Pitch deviation, $f_{\mathrm{pt}}=126$

Fig.32 No.2 gear, $m=1.01, z=72, \alpha=0.98^{\circ}$

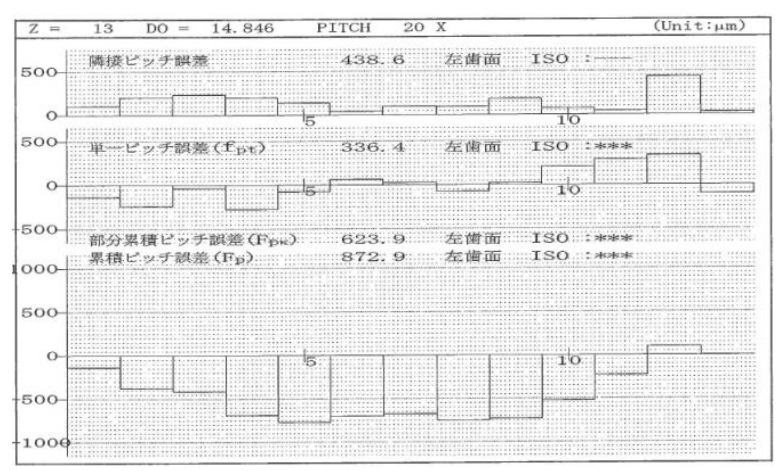

Pitch deviation, $f_{\mathrm{pt}}=336$

Fig.31 No. 2 gear, $m=1.142, z=13, \alpha=18.5^{\circ}$.

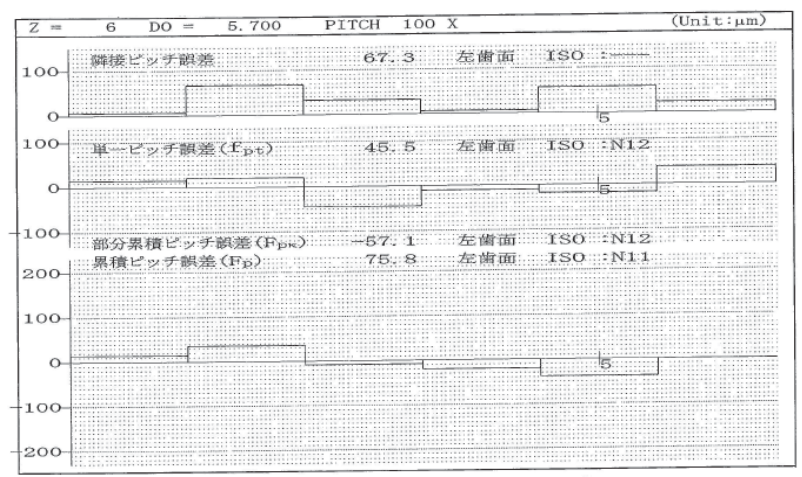

Pitch deviation, $f_{\mathrm{pt}}=45.5$

Fig.33 No.3 gear, $m=1.01, z=6, \alpha=0.98^{\circ}$

Although $\mathrm{z}=72$ is $\mathrm{fpt}=104 \mu \mathrm{m}$ (Fig. 32 ) and $\mathrm{fpt}=126 \mu \mathrm{m}, \mathrm{z}=6$ is $\mathrm{fpt}=45.5 \mu \mathrm{m}$ (Fig.33) which is excellent. However, number of teeth is prime number for $z=13$, the accuracy is very low as $\mathrm{fpt}=336 \mu \mathrm{m}$ (Fig.31).

\section{$4 \cdot 5$ 時計歯車歯形とインボリュート歯形の比較}

図 19 および図 20 では, 時計歯車の歯形をサイクロイド歯形と見なして現物の時計歯車に近い歯車諸元 (表 1) を得たが，これを修整インボリュートとして歯形を作成する．ただし，歯元形状について，現在の歯車の設計お よび製造において歯元形状を単一半径にすることはあり得ないが，時計歯車の歯形に合わせるため歯元を単一半 径として歯形を作成し，図 34 および図 35 の歯車写真上に描いた。 ただし， 2 種類の小歯車および図 35 の大歯 車の歯元形状は，基礎円直径から歯車中心に向から直線で作図している.

図 35 の小歯車の歯元に描いた破線は，時計歯車の形状に一致させた線で描いている．また，図 34 の大歯車の 基礎円直径は歯底円直径とほぼ等しいため, 時計歯車の歯形に合わせるように歯形修整を与え歯元部を直線とし ている．実測した時計歯車の歯形を修整インボリュート歯形としたときの歯車諸元を表 2 に示す．か力合い率を 歯形から求めると 1 段歯車対の歯車のかみ合い率は $\varepsilon=0.307$ であり, 2 段歯車対の歯車のかみ合い率は $\varepsilon=0.513$ と両歯車対とも $\varepsilon<1.0$ である. 


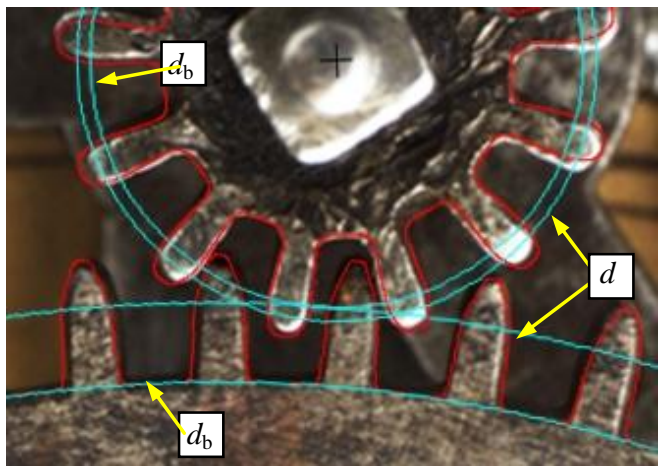

Fig. 341 st gear pair $\left(z_{1}=13, z_{2}=72\right)$.

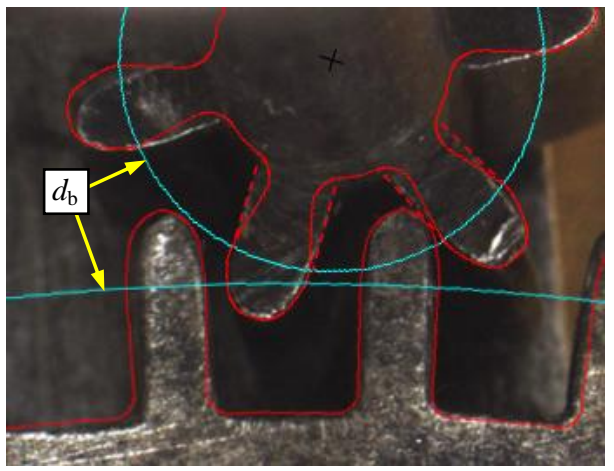

Fig.35 2nd gear pair $\left(z_{1}=6, z_{2}=72\right)$.

Table 2 Gear dimensions (involute spur gears).

\begin{tabular}{|c|c|c|c|c|c|}
\hline Item & unit & \multicolumn{2}{|c|}{ 1st gear pair } & \multicolumn{2}{|c|}{ 2nd gear pair } \\
\hline Gear type & ---- & pinion & gear & pinion & gear \\
\hline Gear No. & ---- & P1 & & \multirow{2}{*}{\multicolumn{2}{|c|}{$\mathrm{P} 2 \underset{1.01}{\mathrm{G} 2}$}} \\
\hline Module & $\mathrm{mm}$ & \multicolumn{2}{|c|}{$\mathrm{P} 1_{1.142^{\mathrm{G}}}$} & & \\
\hline Number of teeth & ---- & 13 & 72 & 6 & 72 \\
\hline Pressure angle & $\operatorname{deg}$ & \multicolumn{2}{|c|}{18.5} & \multicolumn{2}{|c|}{0.98} \\
\hline Reference diameter & $\mathrm{mm}$ & 14.846 & 82.224 & 6.060 & 72.720 \\
\hline Base diameter & $\mathrm{mm}$ & 14.079 & 77.975 & 6.059 & 72.709 \\
\hline Tip diameter & $\mathrm{mm}$ & 16.00 & 84.8 & 7.70 & 74.8 \\
\hline Root diameter & $\mathrm{mm}$ & 10.00 & 78.0 & 3.40 & 69.5 \\
\hline Tip radius & $\mathrm{mm}$ & 0.50 & 0.30 & 0.40 & 0.60 \\
\hline Bottom radius & $\mathrm{mm}$ & 0.40 & 0.45 & 0.30 & 0.30 \\
\hline Facewidth & $\mathrm{mm}$ & 9.2 & 4.2 & 6.80 & 3.5 \\
\hline Center distance & $\mathrm{mm}$ & \multicolumn{2}{|c|}{48.65} & \multicolumn{2}{|c|}{39.45} \\
\hline Contact ratio & ---- & \multirow{2}{*}{\multicolumn{2}{|c|}{0.307}} & \multicolumn{2}{|c|}{0.513} \\
\hline Backlash & $\mathrm{mm}$ & & & \multicolumn{2}{|c|}{1.00} \\
\hline
\end{tabular}

歯車の歯面を顕微鏡（NIKON，SMZ800N+Ds-Ri2）で撮影した写真を図 36〜41 に示す. 大歯車の歯面に着目 すると，図 36(a)および図 39(a)の歯車の歯先のみで摩耗が発生し，小歯車は，図 37(b)および図 38(a)のように歯面 が大きく摩耗している。この摩耗位置は, 図 34 および図 35 のかみ合いと一致している.

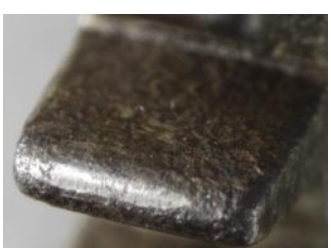

(a) Tooth surface

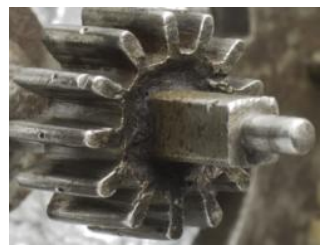

(a) Tooth surface

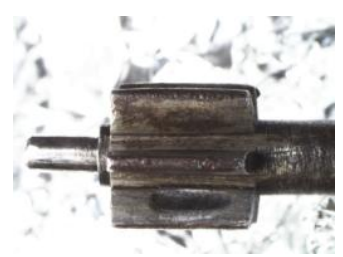

(a) Tooth surface

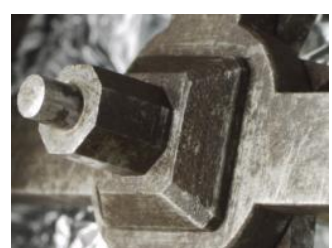

(b) Shaft and joint Fig.36 No.1 Gear (Table 2, G1)

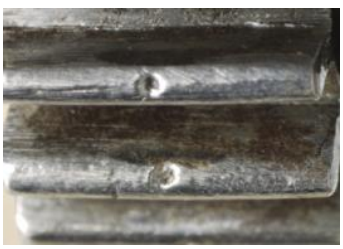

(b) Punch hole Fig.37 No.2

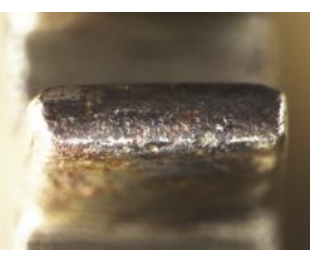

(b) Tooth tip

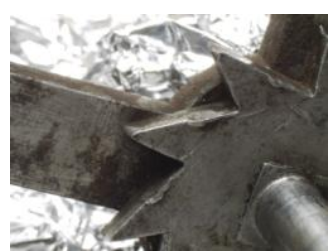

(c) Ratchet

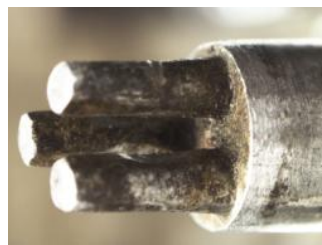

(c) Pin pinion

Table 2, P1).

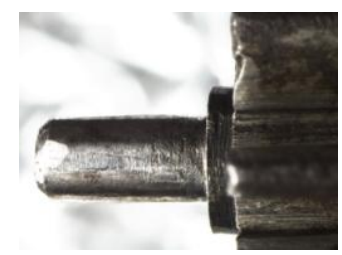

(c) Pinion shaft

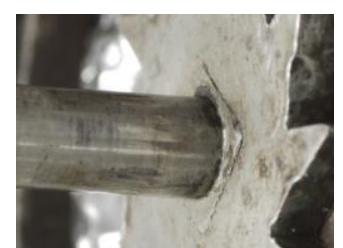

(d) Shaft and joint

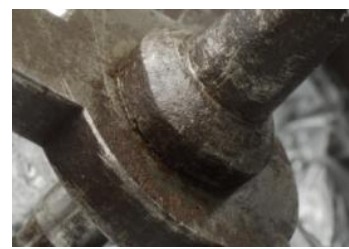

(d) Shaft and joint

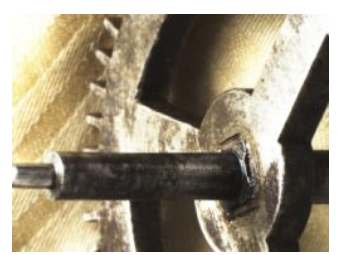

(d) Shaft and joint

Fig.38 No.3 Gear / Pinion (Table 2, P2). 


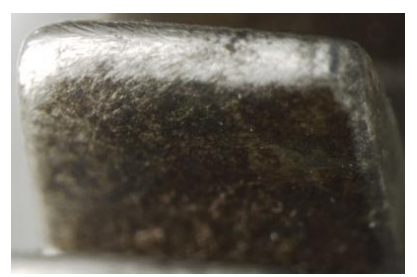

(a) Tooth surface

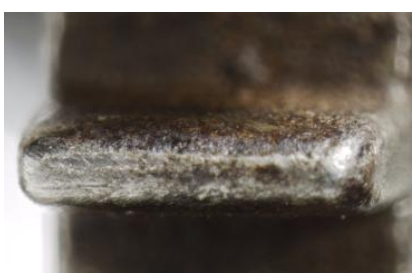

(b) Tooth tip

Fig.39 No.2 Gear (Table 2, G2).

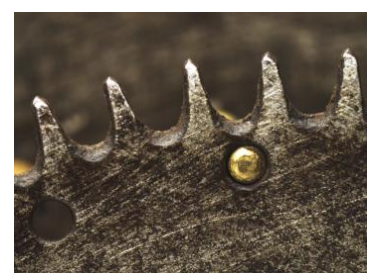

(a) Tooth profile

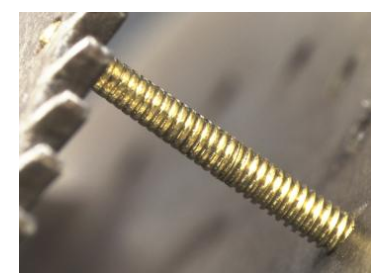

(b) Gear and bolt

Fig.40 24H Gear.

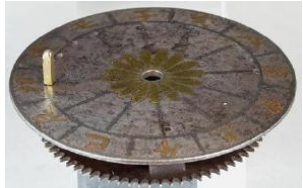

(a) Dial

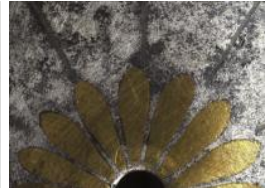

(b)16 petals

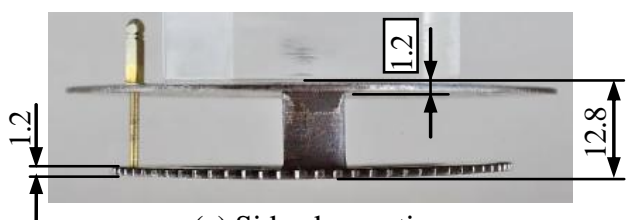

(c) Side observation

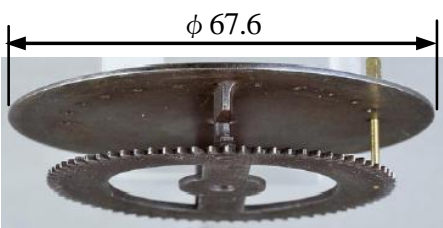

(d) Back observation

Fig.41 24H gear (pin gear).

歯形を観察すると歯面にはエッジ部は認められず滑らかな形状で作られている．また，軸と歯車の嵌合は角穴 であり，図37(c)はサイクロイド系歯形ではなく 3 歯のピン歯車が採用されていることが解る.

図 41(a),(b)の 24 時車の表面に描かれている㐘 16 花紋や時刻分割線そして時刻文字は象嵌細工されている。こ の象嵌細工を調べるため X 線 CT 装置 (Carl Zeiss, METROTOM ${ }^{\circledR}$ )で撮影した。 その結果, 図 42 の画像から象嵌 深さは, 約 $0.37 \sim 0.56 \mathrm{~mm}$ である. また, 24 時車のピン歯車 $(z=72)$ をX 線撮影した図 43 の画像からピン歯車の 歯形や分割穴が鮮明に解る.
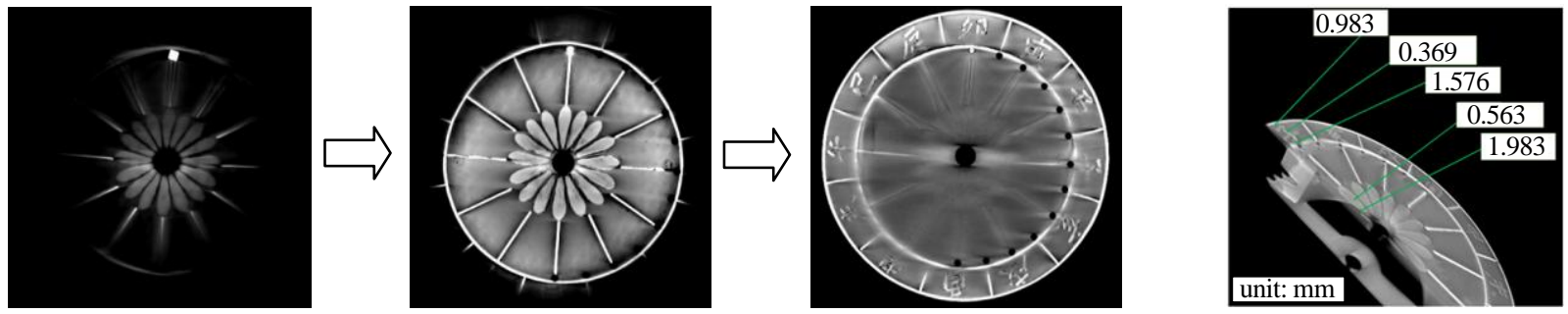

Fig.42 24H Gear / The inlay inspection by the X ray, Disk and inlay character inickness.
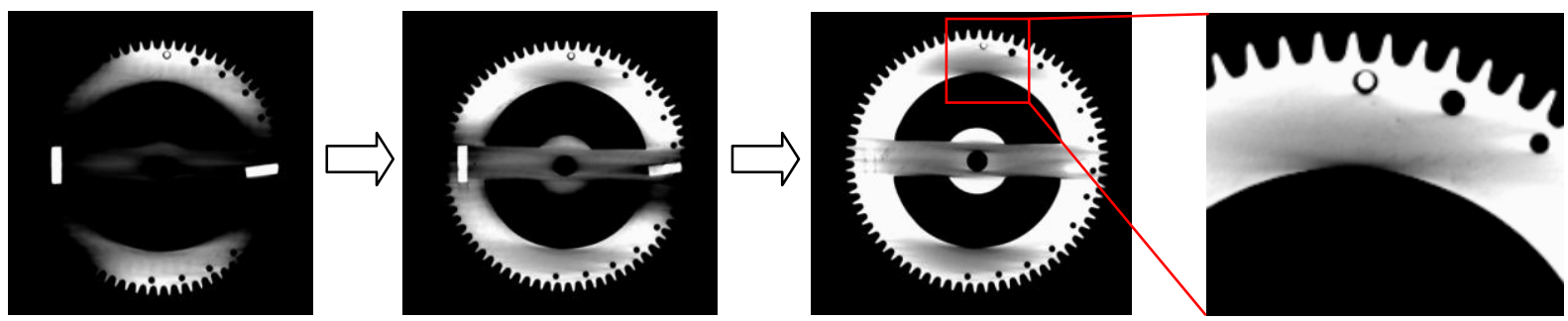

Fig.43 24H Gear inspection by the X ray (Carl Zeiss, METROTOM $\left.{ }^{\circledR}\right)$.

\section{$5 \cdot 1$ 片歯面かみ合い試験}

\section{5. 歯車の評価}

片歯面か夕合い試験機（小笠原プレシジョン，MEATE-3）にて時計歯車の回転伝達誤差およびバックラッシを 計測した. 測定の様子を図 44 に示寸. 図 45 の 1 段歯車対の CCW の測定結果から全か夕合い誤差は $F_{\mathrm{i}}^{\prime}=112$ ' 52 ” で あるが，この值を歯車精度等級 JIS B 1702-1 (1998)で評価すると大歯車（ $z=72 ）$ の N12 級（規格の最悪等級）の 許容值は $F_{\mathrm{i}}^{\prime}=332 \mu \mathrm{m}\left(F_{\mathrm{i}}^{\prime}=277^{\prime} 43^{\prime \prime}\right)$ であることから時計歯車は $\mathrm{N} 12$ 級の 4.1 倍もの偏差を有していることが解る. ただし，歯車精度規格の許容值は，相手歯車をマスタギヤとしたときの許容值であるが，試験結果の $F_{\mathrm{i}}=112{ }^{\prime} 52 ”$ は，時計歯車同士のかみ合い結果である．また， 1 ピッチかみ合い誤差 $\mathrm{N} 12$ 級の許容值は $\left.f_{\mathrm{i}}^{\prime}=124 \mu \mathrm{m}\left(f_{\mathrm{i}}^{\prime}=10^{\prime} 22^{\prime}\right)^{\prime}\right)$ であるが，時計歯車は $f_{\mathrm{i}}^{\mathrm{i}}=42$ ' 47” であることから，これも $\mathrm{N} 12$ 級の 4.1 倍の偏差を持つ歯車である. このように 偏差が大きい理由は，ピッチ誤差が大きいこと，そして，かみ合いに適した歯形でないこと，更に，かみ合い率 が $\varepsilon<1.0$ であることが原因である. なお, $\mathrm{CW}$ 方向と CCW 方向の差であるバックラッシの変化を図 46 に示寸が, このグラフから歯の分割精度（ピッチ誤差）の粗さおよび歯厚が不均一であることが読み取れる. 


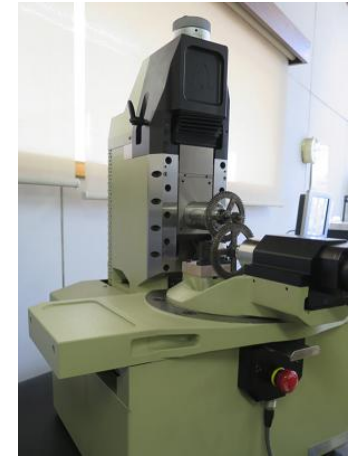

(a) Test rig

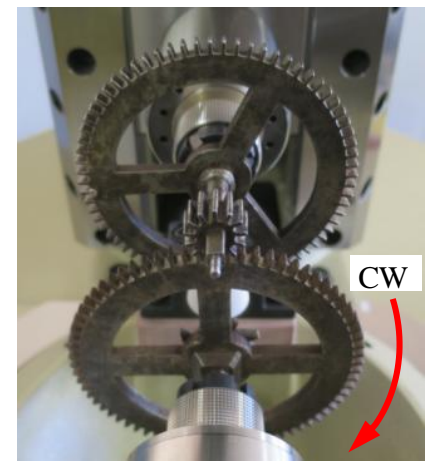

(b) 1 st gear pare $\left(m=1.142, z_{1}=13, z_{2}=72\right)$

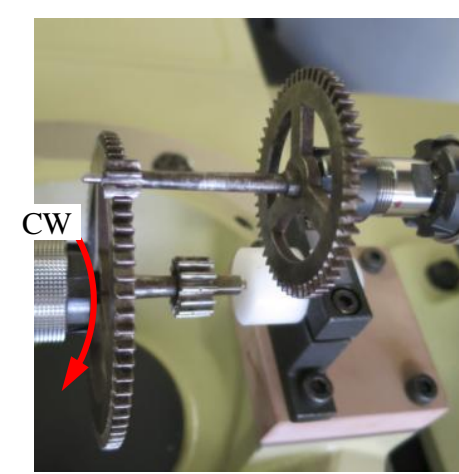

(c) 2nd gear pare, $m=1.01, z_{1}=6, z_{2}=72$ )

Fig.44 Single flank gear tester (Ogasawara precision, MEAT-3).

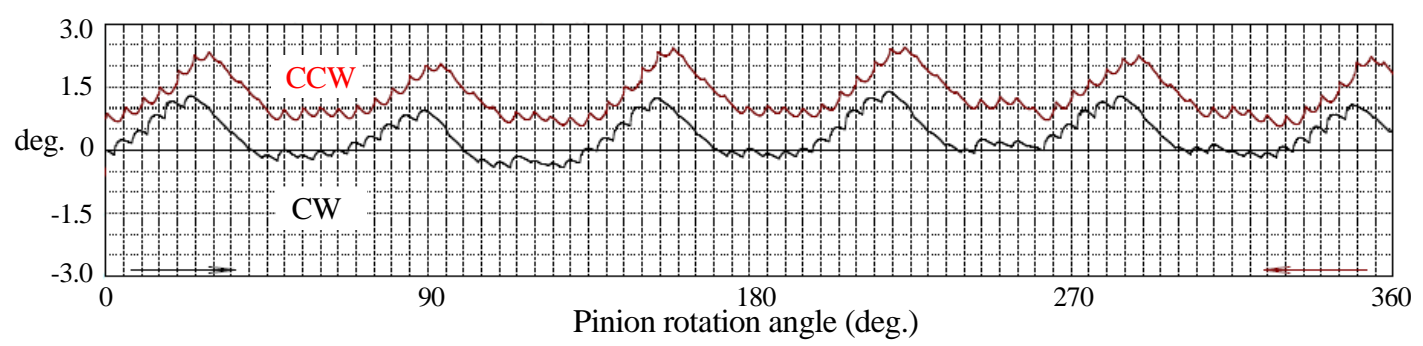

Fig.45 Transmission error, Test result, 1 st gear pare $(\mathrm{P} 1 \times \mathrm{G} 1), m=1.142, z_{1}=13, z_{2}=72$. The effect of pinion $(\mathrm{z}=13)$ pitch error in $1 \mathrm{st}$ gear pair is clearly observed.

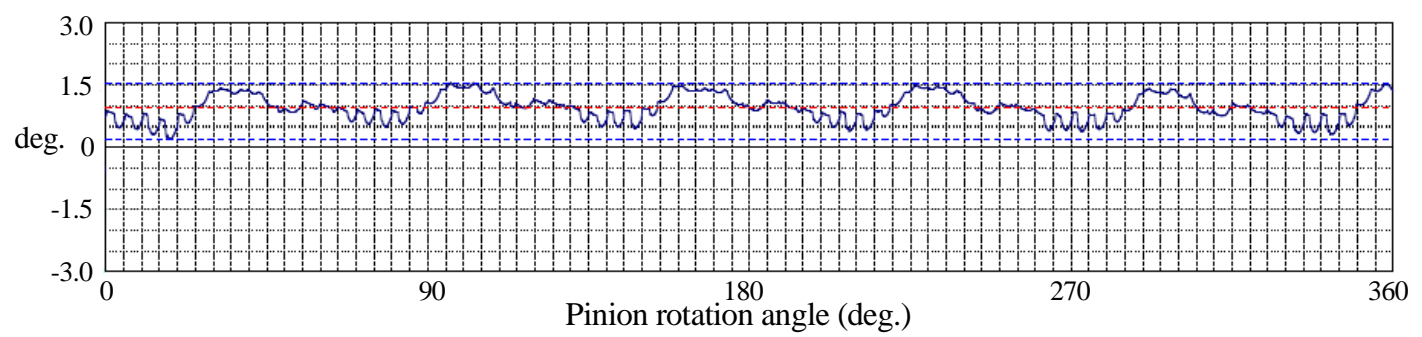

Fig.46 Backlash variation, Test result, 1 st gear pare $(\mathrm{P} 1 \times \mathrm{G} 1), m=1.142, z_{1}=13, z_{2}=72$.

Table 3 Transmission error and backlash.

\begin{tabular}{|l|c|c|c|}
\hline & Mark & CW & CCW \\
\hline Total tangential deviation & $F^{i} \mathrm{i}$ & $108 \mathrm{~m} \mathrm{39s}$ & $112 \mathrm{~m} 52 \mathrm{~s}$ \\
\hline Tooth-to-tooth tangential composite deviation & $f_{\mathrm{i}}^{\prime}$ & $37 \mathrm{~m} \mathrm{33s}$ & $42 \mathrm{~m} \mathrm{41s}$ \\
\hline \multirow{2}{*}{ Backlash } & $j_{\mathrm{n} \_\max }$ & \multicolumn{2}{|c|}{$1 \mathrm{~d} 33 \mathrm{~m} 26 \mathrm{~s}$} \\
& $j_{\mathrm{n} \_\min }$ & \multicolumn{2}{|c|}{ 0d 11m 26s } \\
\hline
\end{tabular}

図 47，48 および表 4 に 2 段歯車対の測定結果を示す. 全かみ合い誤差は $F_{\mathrm{i}}^{\prime}=83$ ’ 02 ”であり 1 段歯車対よりも小 さく, また, 伝達誤差およびバックラッシの変動も小さく表れている. しかし, この值を歯車精度等級 JIS B 1702-1 (1998) で評価すると大歯車（ $z=72 ）$ の 12 級の許容值は $\left.F_{\mathrm{i}}^{\prime}=313 \mu \mathrm{m} （ F_{\mathrm{i}}^{\prime}=29{ }^{\prime} 36^{\prime \prime}\right)$ であることから時計歯車は N12 級の 2.8 倍の偏差を有していることが解る. また, 1 ピッチかみ合い誤差 $\mathrm{N} 12$ 級の許容值は $\left.f_{\mathrm{i}}^{\prime}=105 \mu \mathrm{m}\left(f_{\mathrm{i}}^{\prime}=099^{\prime} 56^{\prime}\right)^{\prime}\right)$ であるが，時計歯車は $f_{\mathrm{i}}=45$ ' 56”であるため N12 級の 4.6 倍の偏差を持つことになる. また，バックラッシの変 化を図 48 に示すが，このグラフから 1 段歯車対よりも 2 段歯車対のほうがバックラッシの変動が少ないが, 波形 から判断して歯の 1 ピッチかみ合い誤差は 1 段歯車対より悪い. これらの結果から，2段歯車対は，1段歯車対よ りも全かみ合い誤差 $\left(F_{\mathrm{i}}^{\prime}\right)$ は小さいが， 1 ピッチかみ合い誤差（ $f_{\mathrm{i}}^{\prime}$ ) は大きい. そのため，2段歯車対は，1段歯

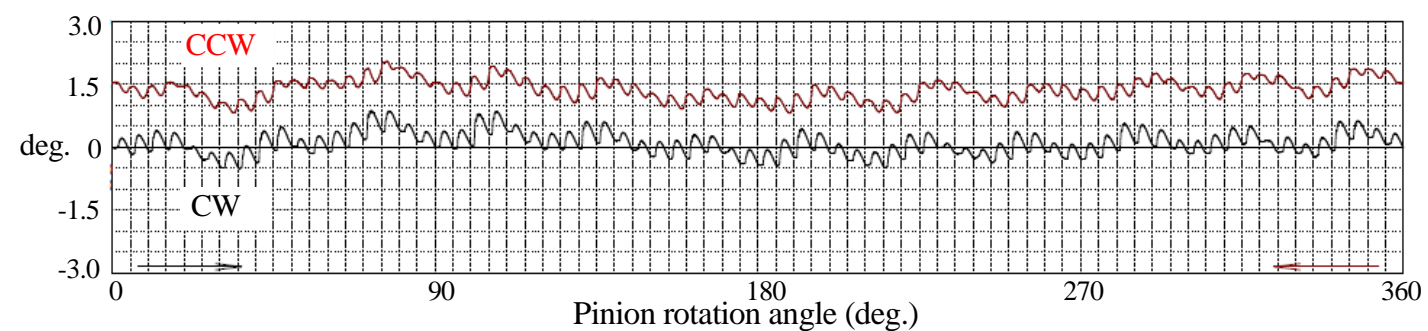

Fig.47 Transmission error, Test result, 2nd gear pare $(\mathrm{P} 2 \times \mathrm{G} 2), m=1.01, z_{1}=6, z_{2}=72$. 
Ueda, Watanabe, Miyazaki, Kubo and Matsuoka, Transactions of the JSME (in Japanese), Vol.83, No.847 (2017)

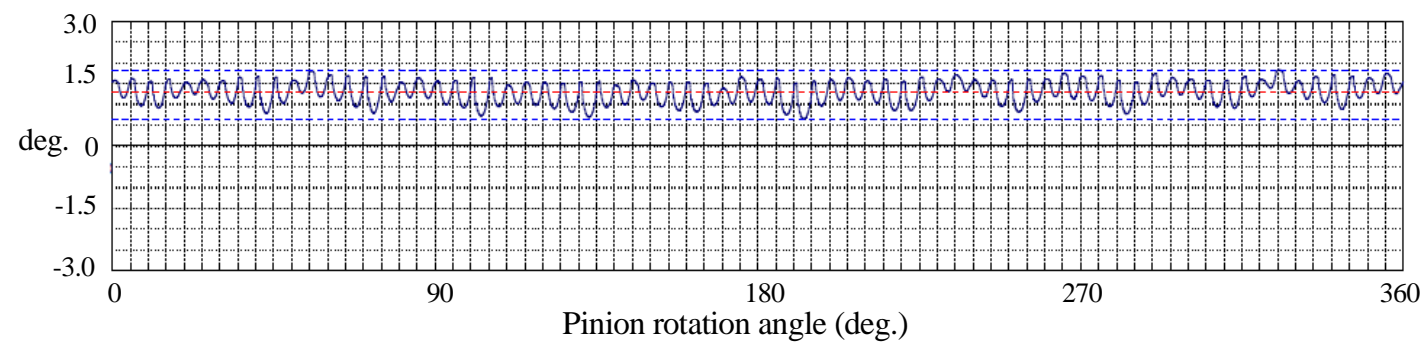

Fig.48 Backlash variation, Test result, 2nd gear pare $(\mathrm{P} 2 \times \mathrm{G} 2), m=1.01, z_{1}=6, z_{2}=72$.

車対よりもかみ合いに適した歯形ではないと言える. 伝達誤差を円グラフとして表した図 49 および図 50 から伝 達誤差変動を読み取ると，1 段歯車対の小歯車（z=13）のピッチ誤差の影響が明確に表れている.

Table 4 Transmission error and backlash.

\begin{tabular}{|l|c|c|c|}
\hline & Mark & $\mathrm{CW}$ & $\mathrm{CCW}$ \\
\hline Total tangential deviation & $F^{\prime} \mathrm{i}$ & $83 \mathrm{~m} 02 \mathrm{~s}$ & $73 \mathrm{~m} 42 \mathrm{~s}$ \\
\hline Tooth-to-tooth tangential composite deviation & $f_{\mathrm{i}}^{\prime}$ & $45 \mathrm{~m} 56 \mathrm{~s}$ & $32 \mathrm{~m} \mathrm{49s}$ \\
\hline \multirow{2}{*}{ Backlash } & $j_{\text {n_max }}$ & \multicolumn{2}{|c|}{$1 \mathrm{~d} 49 \mathrm{~m} \mathrm{32s}$} \\
& $j_{\text {n_min }}$ & $0 \mathrm{~d} \mathrm{38m} \mathrm{04s}$ \\
\hline
\end{tabular}

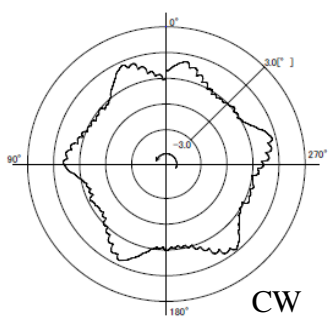

Fig.49 Test result (1st gear pare, $m=1.142, z_{1}=13, z_{2}=72$ ).

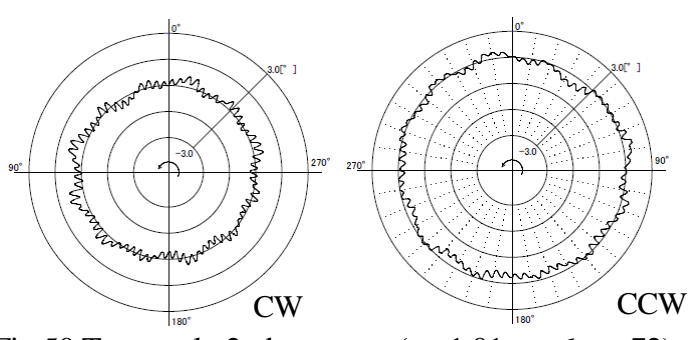

Fig.50 Test result, 2nd gear pare $\left(m=1.01, z_{1}=6, z_{2}=72\right)$.

本来，サイクロイド歯車のかみ合いでは，図 19 および図 20 のようなかみ合い（ $\varepsilon>1.0 ）$ となるが，計測した 歯車対では, 表 3 および表 4 のように大きな伝達誤差を持つ歯車であることが判明した. そして，これらの歯車 対のかみ合い率は 1 未満であるが, 回転速度は $n=1.39 \times 10^{-3} \mathrm{~min}^{-1}$ (1 段歯車の場合) と小さく, また, 時計歯車と しては 1 歯ごとの送りピッチ移動が作用すれば機能を満たすことになるため，この時代の時計としては大きな問 題にはならなかったということができる.

\section{$6 \cdot 1$ 硬さ測定}

\section{6. 歯車材料}

図 51(a)に示す 1 番歯車のリム部に 5mm 角の範囲（黄色枠）を\#1200，\#2000，\#3000 のエメリー紙で研磨後， マイクロビッカース硬度計 (荷重 $0.98 \mathrm{~N}$, 負荷時間 $15 \mathrm{~s}$ ) により表面硬さ測定 (島津製作所製, 微小硬度計, HMV-G20S) を行った（硬さ測定 1 回目）。測定位置は $5 \mathrm{~mm}$ 角枠内の「・」位置（測定基準位置を 1-1 とする）を基準点とし， 右方向へ 3 点（測定位置 2４），下向へ 3 点（测定位置 5〜7），上方向へ 3 点（測定位置 8〜 10）を $0.1 \mathrm{~mm}$ 間隔 で測定した．また，歯車の歯元 $\mathrm{A} \sim \mathrm{C}$ およびリ ム内周近傍 $\mathrm{D}$ の位置で表面に光沢ある部分を測定位置とした．測

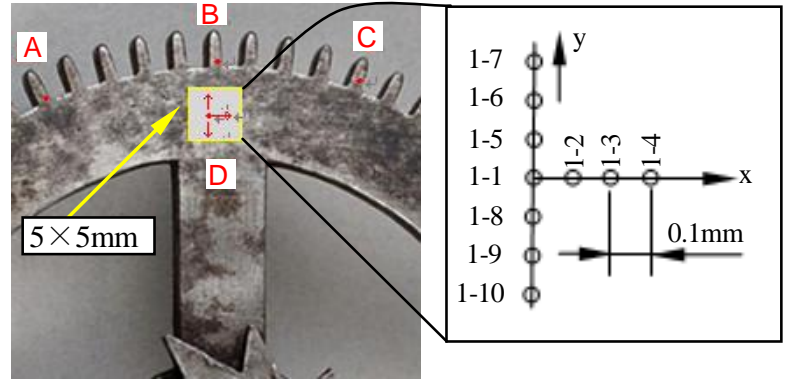

(a) Hardness inspection area

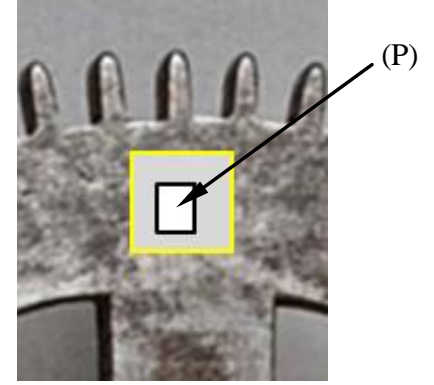

(b) Material histological-tissue-examination area, (P)

Fig.51 No.1 Gear / material inspection. 
定結果を表 5 および表 6 に示す．研磨面の表面硬さは HV201～223 の硬さを呈し，その変化は少ない．未研磨面 (A〜D) での測定值は表面がビッカース圧痕により菱形に歪む圧痕も見られたが硬さは研磨面の結果と大きな差 異は認められない，次に組織観察をするため図 51(b)の $5 \mathrm{~mm}$ 角内をさらに研磨仕上げを行い, 金属顕微鏡 (NIKON 製, OPTIPHOT）により腐食前表面観察を実施した。更に4\%ナイタル液で腐食後, 表層部組織観察を行い, そ の後，2 回目の硬さ測定を行った．硬さ測定結果を表 7 に，硬さ測定後の顕微鏡写真を図 52 に示寸.

Table 5 Hardness distribution (After polish), Fig.51 (P).

\begin{tabular}{|c|c|c|c|c|c|c|c|c|c|c|}
\hline Measuring position & $1-1$ & $1-2$ & $1-3$ & $\overline{1-4}$ & $1-5$ & $1-6$ & $1-7$ & $1-8$ & $1-9$ & $1-10$ \\
\hline Hardness $\quad \mathrm{HV}(0.1 \mathrm{~g})$ & 210 & 211 & 203 & 210 & 208 & 210 & 201 & 215 & 223 & 208 \\
\hline
\end{tabular}

Table 6 Surface hardness in the deddendum point.

\begin{tabular}{|l|c|c|c|c|}
\hline Measuring position & A & B & C & D \\
\hline Hardness $\mathrm{HV}(0.1 \mathrm{~g})$ & 201 & 193 & 215 & 228 \\
\hline
\end{tabular}

Table 7 Hardness distribution (After corrosion processing), Fig. 52.

\begin{tabular}{|l|c|c|c|c|c|c|c|c|c|c|}
\hline Measuring position & $2-1$ & $2-2$ & $2-3$ & $2-4$ & $2-5$ & $2-6$ & $2-7$ & $2-8$ & $2-9$ & $2-10$ \\
\hline Hardness $\mathrm{HV}(0.1 \mathrm{~g})$ & 193 & 200 & 196 & 189 & 194 & 197 & 172 & 195 & 188 & 186 \\
\hline
\end{tabular}

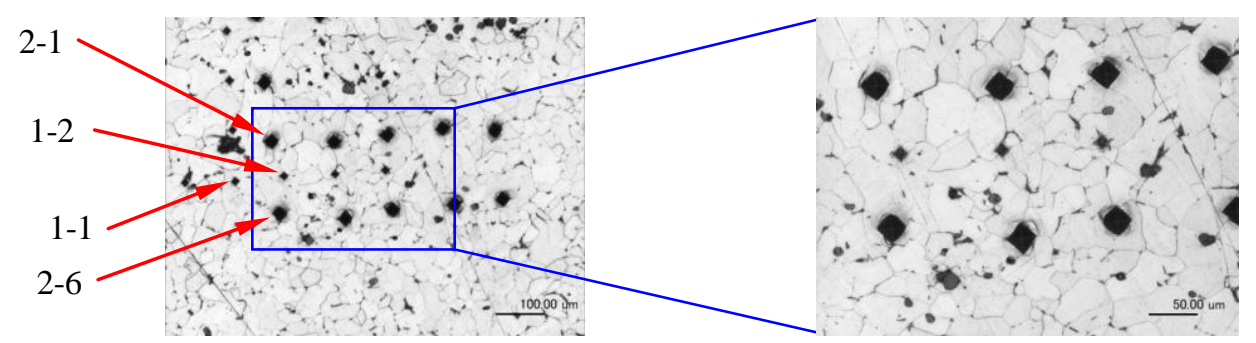

(a) Hardness measurement area $(\times 100)$

(b) Vickers impression and HV $(\times 200)$

Fig.52 Microphotograph after hardness measurement.

\section{$6 \cdot 2$ 表層部組織観察結果}

図 51(b)の(P)領域内を $1 \mu \mathrm{m}$ のダイヤモンドペースト（DP）で研磨後，金属顕微鏡（NIKON 製，OPTIPHOT） により表面観察した. 研磨後の表面は多くの酸化物が存在し, 図 53(c)には大きな酸化物が認められる.この画像 から酸化物の表面に他の物質被膜が存在する.この物質はデンドライト状を呈する皮膜であり鍛冶工程で加熱に よる最表面の酸化被膜が鍛造により再付着したものと考えられる. 次に, 図 53(b)中央部を拡大した微分干渉視野 観察（NIKON 製，顕微鏡デジタル撮影装置 DS-U1，ACT-2U）結果を図 54(a)に，図 53(c)を DP により更に研磨 を行った後の微分干渉視野を図 54(b)に示す. 微分干渉視野では研磨キズ，異物等が明膫に観察することができ， 図 54(a)中に示す○で囲んだ異物は硫化物と推察される形態を呈する. 図 54(b)では再度の研磨により被膜が部分 的に剥離した状態が観察できる.

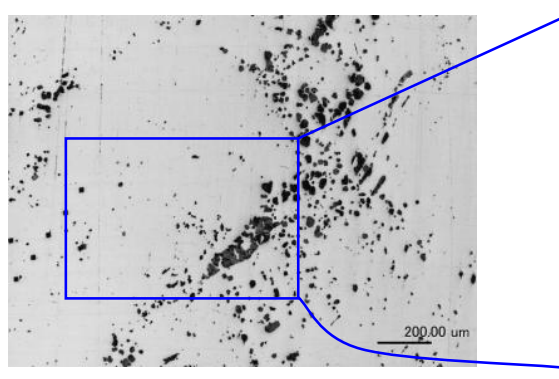

(a) surface, scale $\times 50$

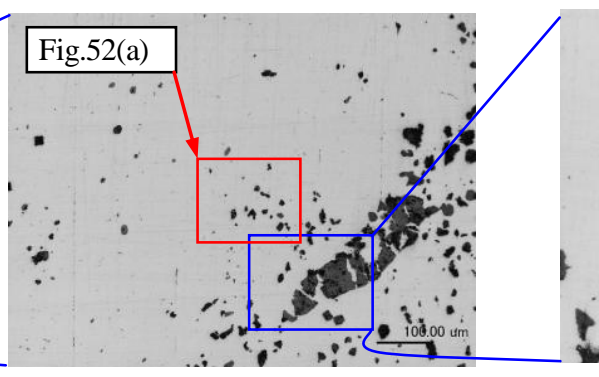

(b) surface, scale $\times 100$

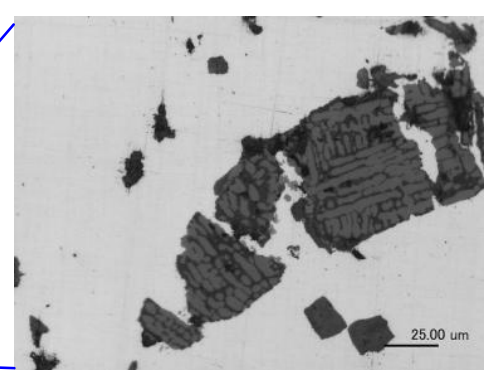

(c) big oxide, scale $\times 400$

Fig.53 The surface part after polish (polish flaw, oxide, rusts, sulfuret). 


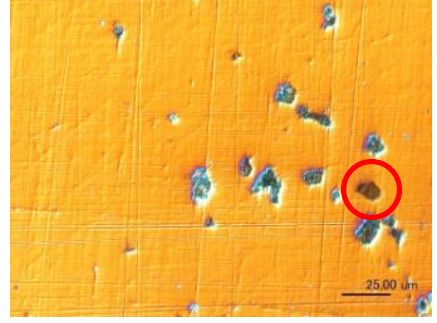

(a) Magnification of oxide and alien substance in the surface after polish, scale $\times 400$

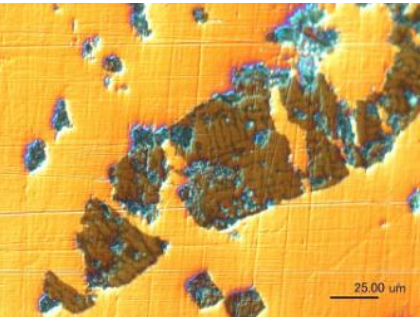

(b) Big oxide in the surface and the film adhesion after polish, scale $\times 400$

Fig.54 The surface part after polish, oxide and sulfur (differential interference contrast microscope).

図 55 に研磨面 4\%ナイタル液で腐食し, 観察位置を変更した表面部組織観察結果を示寸. 表層部組織は多くの 酸化物の残存が多く見られ，これらの酸化物は表面に発生した酸化物が内部に至ったものと推察される.また, 粒状の硫化物が点在していることも確認できた。歯車材料の表層部組織の結晶粒は小さく, フェライトと粒内に 炭素が極僅かに溶け込んだ結晶粒と粒界に黒色の組織が現れている。これらの組織はパーライトであり，フェラ イトとパーライトの面積比率から推察して本材料は 0.07〜0.09\%C を含む炭素鋼であると考えられる.

この材料は丁寧に鍛錬されていることから，本和時計の製作には刀鍛冶の流れを汲む鉎冶が関わっている可能 性がある. 初代津田助左衛門は尾張藩（徳川家）附家老の竹腰古山城守（正信）から扶持を得ていた（名古屋市 史，1980）ため三代目津田助左衛門も刀鍛冶の可能性があると考えられる.

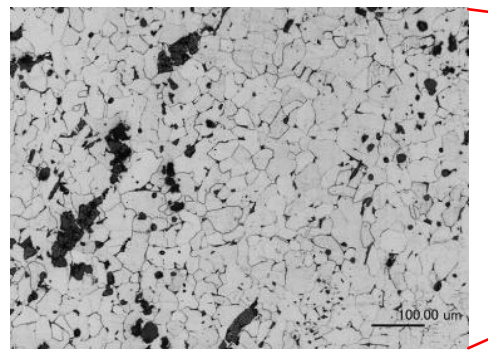

(a) scale $\times 100$

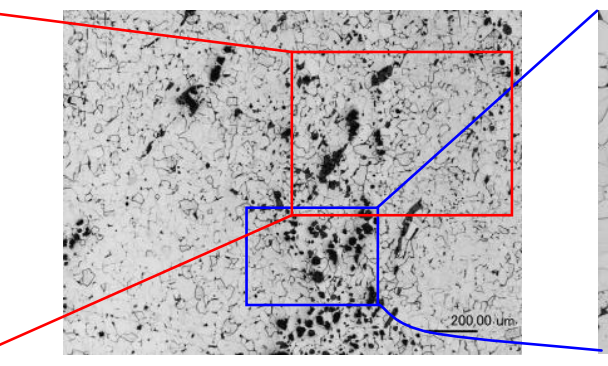

(b) scale $\times 50$

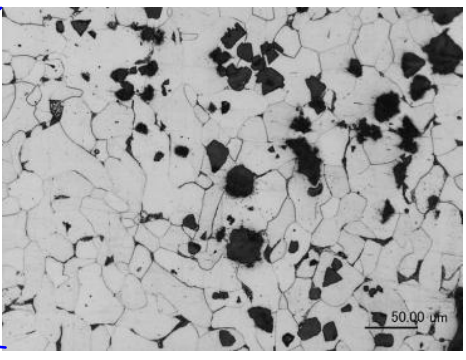

(c) scale $\times 200$

Fig.55 Metal structure photograph (observation position 1), HV, position Fig.49, 1-1. The crystal grains of the gear material surface are small, while ferrite, slightly dissolved carbon crystal grains and some black compound in grain boundaries are observed.

\section{$6 \cdot 3$ 現在市販されている材料との比較}

時計歯車の材料の硬度分布および組織写真を $6 \cdot 1$ および $6 \cdot 2$ に示したが，これと，現在，市販されている冷間 引き抜き棒鋼材（S25C，焼準材，2014 年，特殊鋼メーカ）とを比較する．なお，時計材料に近い S10Cで比較す るのが良いと思われるが，S10C は入手困難な鋼種であること，また，炭素含有率と硬度の関係を比較する目的で あることから S25C 材料とした．試験片は，直径 $40 \mathrm{~mm}$ （長さ $70 \mathrm{~mm}$ ）の丸棒に旋削加工を施し直径 $39 \mathrm{~mm}$ とし， 大気炉で $900^{\circ} \mathrm{C} ， 60$ 分加熱後空冷した試験片により硬さ測定と組織観察を実施した. 全長 $70 \mathrm{~mm}$ の試験片の中央 部で長さ $10 \mathrm{~mm}$ の長さで切断し, 図 56 のように軸直径方向に切断した試料を用いて硬さ測定をマイクロビッカ 一ス硬度計（島津製作所製，微小硬度計，HMV-G20S）で荷重 $0.98 \mathrm{~N}$ ，負荷時間 $15 \mathrm{~s}$ とし，図 56 のように断面内 で半径方向に測定を行った（川上，2014）.

硬さ測定後の試験片より採取した試料の断面組織観察結果を図 57 に示す. 試験片の焼きならし組織は, 市販品 に比べ僅かに炭素の拡散が見られ，フェライト・パーライトの層状組織が小さくなっている.

試験片（図 56）の硬さ分布および時計歯車（図 51）の硬さ測定結果を図 58 に示すが，測定位置を考慮して両 者を比較すると時計歯車材料の炭素含有率は 0.07 0.09\%であるにも関わらず, 試験片の S $25 \mathrm{C}$ より HV20 程度大 きい值を示している．また，組織観察では粒界に見られるパーライトが均一に分散し，結晶粒も小さいことから 時計材料の方が現在の市販材料より丁寧に鍛錬，熱処理されていると判断することができる.

図 58 の時計歯車の硬さ分布でNo.2-7（HV172）は他の硬さに比して約 HV20 低下している. また，図 59 のよ うに測定圧痕が僅かに歪んでいる理由は，HV 測定子がフェライトの部分に落ち込み，粒界パーライトと，その 隣のパーライト結晶粒（炭素の溶け込みは微量）の影響によるものと考えられる. この No.2-7 を除くと, 時計 


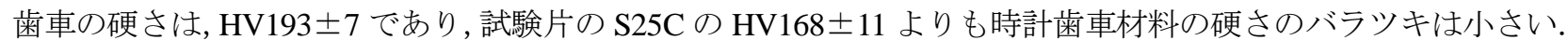

最近の鋼材では硫化マンガンが筞状に存在して鋼材の強度を弱めていることがかなり一般的であるが，この歯 車材料では硫化マンガンが細かい粒状で内部に分散している。このことから時計歯車材料のほうが現在の市販品 材料より丁寧に鍛錬，熱処理されている.

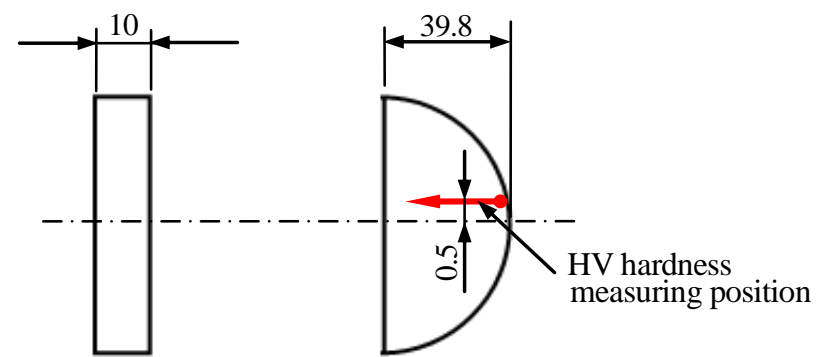

Fig.56 Measuring positions of Micro-Vickers hardness test.
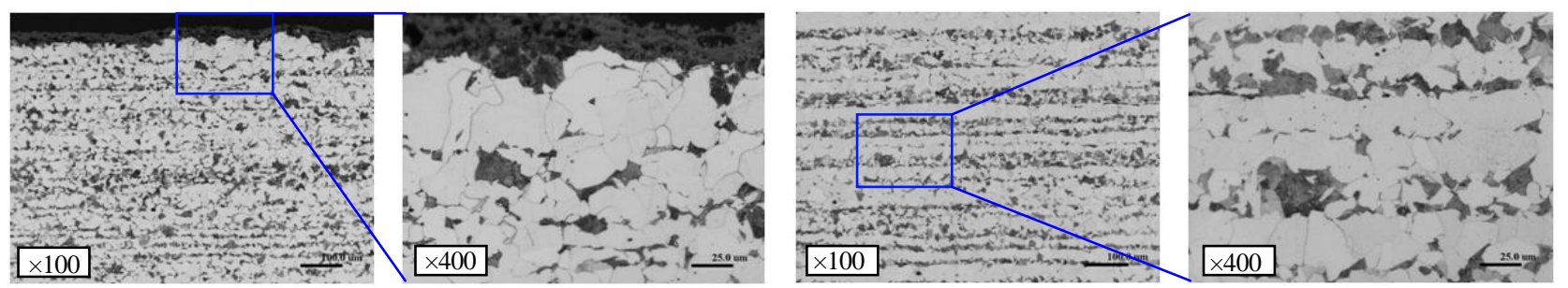

Fig.57 Metal structure of Today's standard material S25C. The steel is normalized in atmospheric fire furnace.

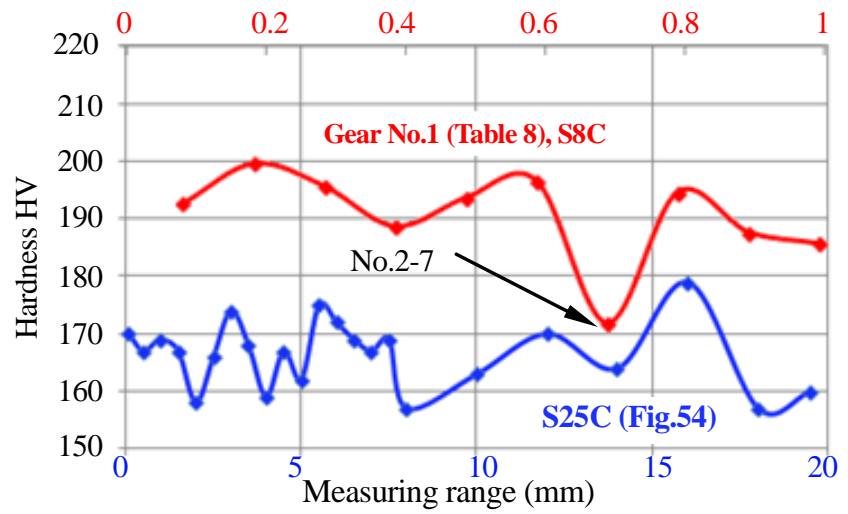

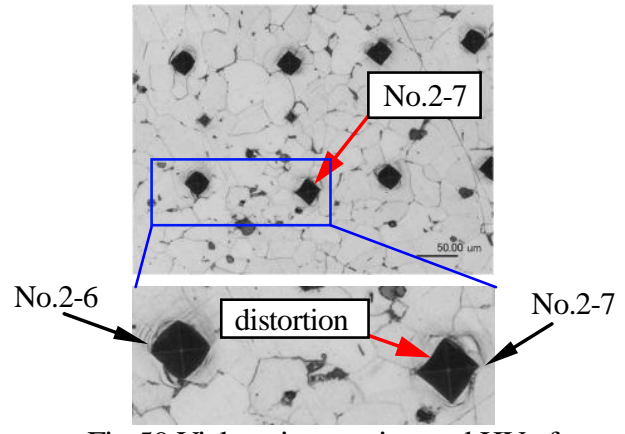

Fig.59 Vickers impression and HV after corrosion processing $($ scale $\times 200)$

Fig.58 The hardness of the watch gear blank material and the test block.

Although carbon content of the clock gear material is 0.07 to $0.09 \%$, it is about HV200 higher than S25C of the test piece.

Therefore, the clock gear material is found to be higher quality than commercially available materials.

\section{$7 \cdot 1$ 試料分析}

\section{7. 潤滑油}

和時計歯車には，どのような潤滑油が使われていたのかを知るため，図 60 のように歯車と軸の接合部に極僅か 残っていた油分らしき微細粒を採取し，SEMによる外観観察と赤外線分光法（Infrared spectroscopy）による定性 分析，そして元素の半定量分析（Thermo Fisher Scientific Inc., Nicolet iN 10, 赤外顕微鏡）を実施した.

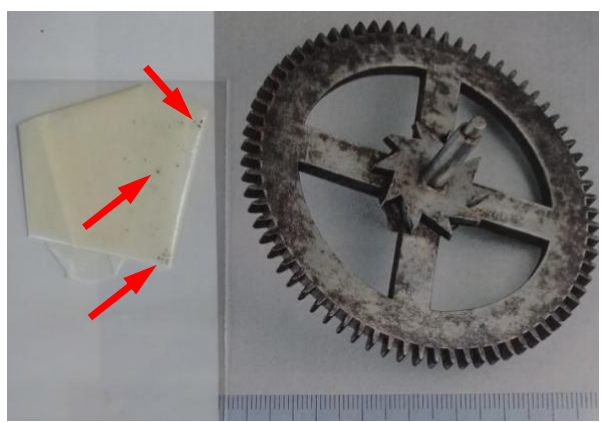

Fig.60 Lubricating oil (minute grain) and 1st gear.

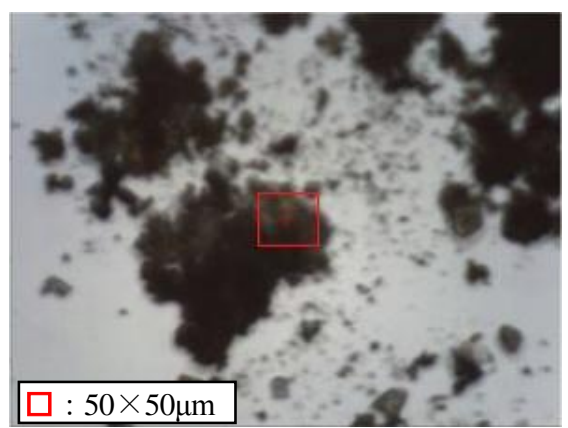

Fig.61 Microphotograph of minute grain. 
分析の結果，IR チャートの図 62(a)には $1736 \mathrm{~cm}^{-1}$ にエステルと思われる吸収が認められ，図 62(b)には $1711 \mathrm{~cm}^{-1}$ にカルボン酸の吸収が認められた. また, 1030〜 1040 $\mathrm{cm}^{-1}$ の範囲は土あるいは砂と推測することができる. なお, は炭化水素を, \&は水酸基を示している.

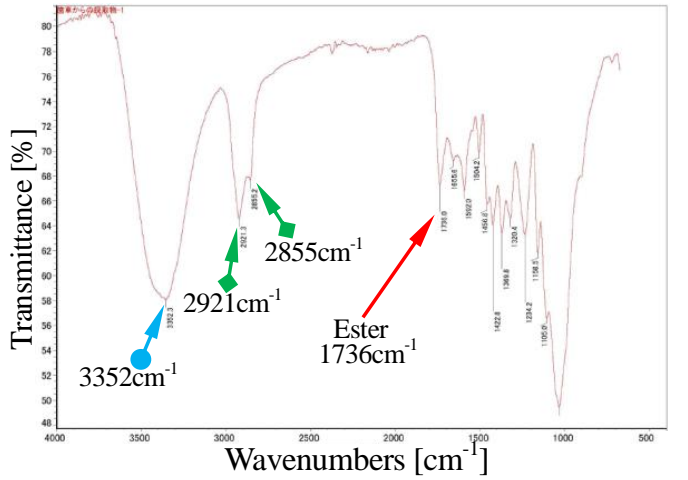

(a) position 1

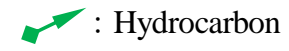

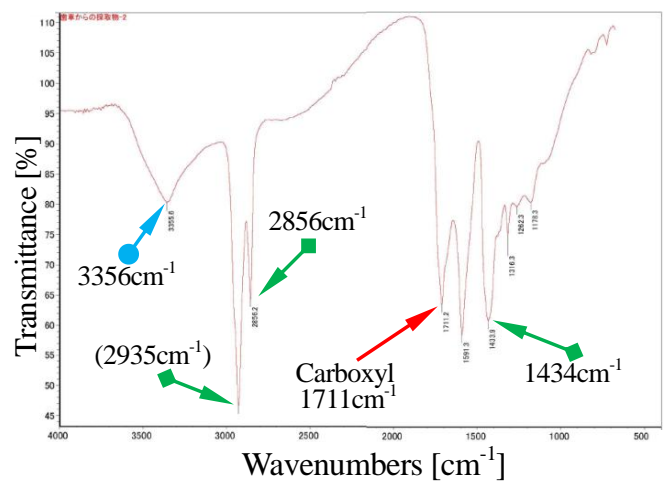

(b) position 2

Fig.62 IR chart, The absorption to seem Estelle by $1736 \mathrm{~cm}^{-1}$ of was admitted by the Fig. 62(a) of the IR chart and in Fig. 62(b), the absorption of the carboxylic acid was admitted by $1711 \mathrm{~cm}^{-1}$. It is possible to suppose that the range of $1030-1040 \mathrm{~cm}^{-1}$ is earth or sand.

ランダムに選択した試料（図 61）のSEM 観察と EDS（エネルギ分散型 X 線分析）の結果を図 63 および図 64 に示寸.この分析結果から判断できることは, 最も含有率の多い $\mathrm{C}$ の由来が炭化水素とすれば $\mathrm{C}$ と $\mathrm{O}$ の比率バ ランスから炭化水素以外の $\mathrm{C}$ が含まれていると考えられる。 $\mathrm{O}$ は酸化物， $\mathrm{Si}$ および $\mathrm{Al}$ は，土や砂， $\mathrm{K}$ や $\mathrm{Na}, \mathrm{S}$ は，たんぱく質にも含まれている元素であり $\mathrm{Cu}$ は，図 10(b)に示した軸受けメタルの銅かもしれない．図 64 視 野の元素分析結果を図 65 に示寸.

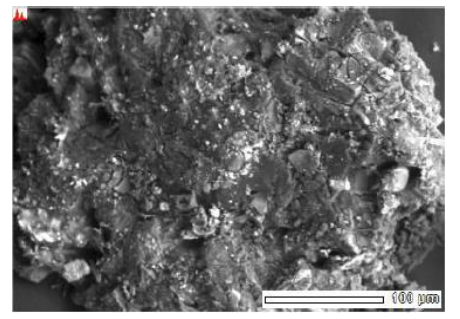

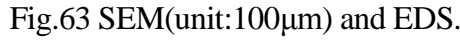

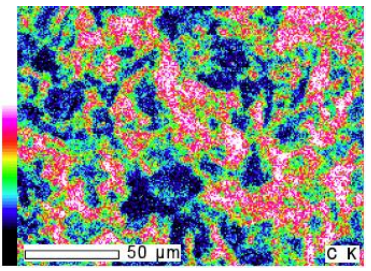

(a) Carbon

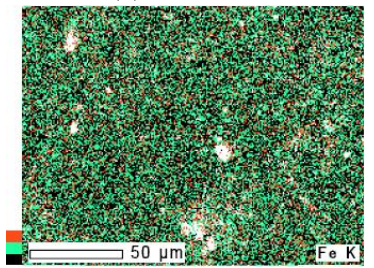

(e) Iron (Ferrum)
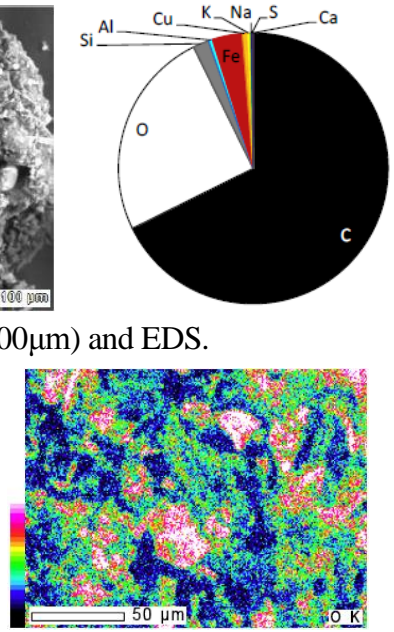

(b) Oxygen

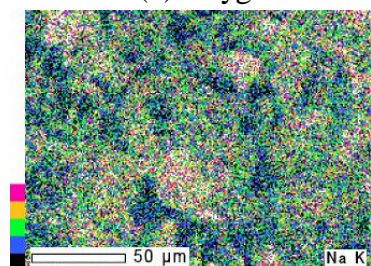

(f) Sodium (Natrium)
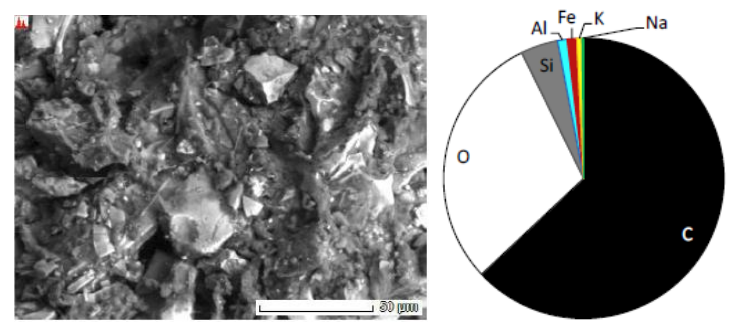

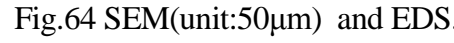

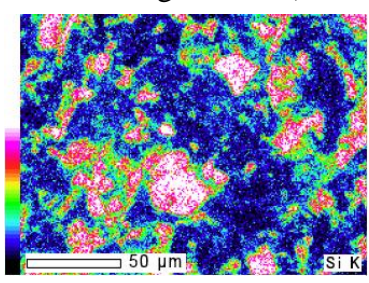

(c) Silicone

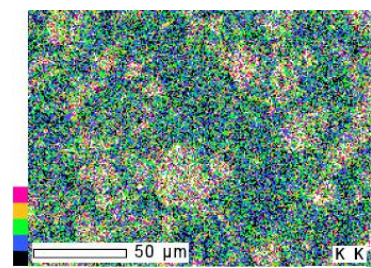

(g) Potassium (Kalium)

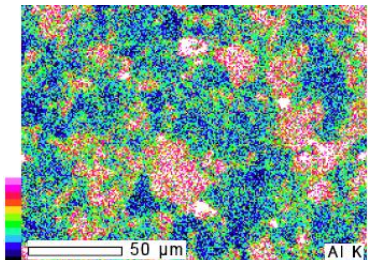

(d) Aluminum

Fig.65 Element distribution.

\section{$7 \cdot 2$ 潤滑油についての考察}

和時計歯車の潤滑油と思われる試料（図 60）からカルボン酸の吸収（図 62）が認められたことから油脂（脂肪 酸が主成分）と推定することができる. また，エステル（図 62）の吸収が存在することから動物性油脂の可能 
性があるが，植物性油脂にもエステルが含まれているこのことから，本分析結果からは，植物性油脂であるの か動物性油脂であるのかは特定できない.

図 63 および図 64 から炭素の比率は炭化水素比率よりも多く存在する.また, 試料の外観が黒い理由は, 固定 潤滑材として炭素（例えば “す寸”）を意図的に混入していたかも知れない．なお，防錆処理材として漆を使用し ていたことから図 62 の水酸基は，漆の主成分であるウルシオール（図 66）の可能性が高い. 和時計の潤滑油 としてどのようなものが使われていたのか, 今回の分析の結果からは結論付けることが出来なかった. また, EDS 分析結果に含まれる元素には時計材料（機械要素，象嵌材料，潤滑油，表面処理材料）の他にも，製造時 の 道 具やその後の管理も含めた履歴物質も含まれるため, これらを考慮して分析結果を判断する必要がある.

\section{8. 結}

三代目津田助左衛門信貫が貞享五年（1688 年）に製作した二挺天符櫓時計に使われている歯車について調査を 行った結果, 以下のことが解った.

(1) 新しい発見としては, 328 年前の時計歯車の歯形はサイクロイドに近いものであるが，歯形理論に基づいて は製作されていない。

(2) 1851 年に製作された田中久重の「万年自鳴鐘」に使われている歯車も単なる” ひっかかり歯車” であり, 歯 形理論に基づいて設計された形跡は見られない．このことから我が国では，歯形理論に基づく歯車の製造は されていなかったと考えられる.

(3) 歯形にエッジは無く, 全歯均等に作られていてクラウニングが施されている. このことは, 歯のかみ合いに 関して非常に有用なことであり，航空機用歯車にエッジ部がないのと同様である.この当時の技術者は歯に エッジを付けてはいけないということを経験で承知していたのかも知れない.

(4) 歯先の外周振れは, 手作りにも関わらず $0.1 \mathrm{~mm}$ と高精度である.

（5）時計歯車の材料は，328 年経過した現在でも錆びていない，その結晶粒は極めて微細で一様であり，また， 鉄鋼中に不可避的に存在する介在物もクラスターになっているところがない. また，0.08\%炭素鋼（S8C）で あるにも関わらず, S25Cよりも硬く, 組織も美しいため, 現在の材料よりも丁寧に鍛錬, 熱処理されている と言える.

（6）本和時計の製作者である津田助左衛門信貫が，刀鍛冶の流れを汲む鍛冶であったということは今回の文献調 査では補強できなかった。この調査に関しては今後の課題としたい.

(7) 採取した潤滑油らしき試料の成分は判明したが，この試料には様々な履歴成分が含まれている．そのため潤 滑油の種類（動物性なのか植物性なのかも含め）の特定に関しては今後の課題としたい.

\section{謝 辞}

本研究に際し，大阪精密機械(株)の竹田龍平氏に歯形測定の依頼を，(株)小笠原プレシジョンラボラトリーの 前田憲次氏には片歯面かみ合い試験を, 応用科学研究所の原正丈氏には時盤の X 線撮影を, そして, 出光興産(株) の田本芳隆氏には油分析を快く引き受けていただいた。 また，国立科学博物館名誉館員の佐々木勝浩氏および和 時計学会研究員の近藤勝之氏には和時計について様々な情報を提供いただいた．さらに，製作者および製作年が 明確である貴重な文化財ともいえる和時計の歯車に組織検查のためとはいえ傷を付けることを許可いただいたセ イコーミュージアム社には深く感謝申し上げます，この研究により 330 年ほど前の日本に，このような歯車技術 があったことを発見できたことは歯車に携わる我々にとって貴重な財産であることは間違いのないところです. 本研究にご支援いただいた皆様方に深く感謝申し上げます.

\section{文献}

会田俊夫, 歯車の設計(1), 大河出版(1971), p.1, p.45, p.48.

会田俊夫，歯車の技術史，開発社(1970), p.666.

相賀徹夫, 日本大百科全書, 小学館(1988), p.813.

サイクロイド歯車ソフトウェア Manual, AMTEC INC.(2002).

深川英俊, Dan Solowsky, 日本の数学 何題解けますか[上], 森北出版(1995), p.48. 
塙保已一編纂, 「大内義隆記」, 『群書類従』, 巻三九四(1819), 合戦部二六, p.26.

平山諦，円周率の歴史，大阪教育図書(1980), p.280.

Hoeve , J. and Thompson, D., A fremsh clock at the shogun's shrine antiquarian horology, Vol.35, No.4 (2014), pp.10631076.

川上万葉，鋼の表層強化特性に及ぼす高周波加熱・焼入条件の影響評価，京都工芸繊維大学卒論(2014), p.11. 河本信雄，日本での機械時計製作開始時期の考察，佛教大学鷹陵史学会，No.39(2013), pp.149-173.

久保田祐二，万年時計の機構解明，東芝レビューVol.60 No.7(2005), pp.116-119.

名古屋市編，名古屋市史復刻版，愛知県郷土資料刊行会(1980), p.159.

小田幸子，和時計図録，セイコー時計資料館蔵(1994), p.5, p.100.

岡山県立博物館, 平成 19 年度特別展吉備津神社(2007), p.91.

小谷年司，ロバートソンの「日本の時計」について，和時計学会，No.42 (2010),p.5.

佐々木勝浩, 近藤勝之, 津田助左衛門の和時計と特徴, 和時計学会, No.42(2010), pp.16-29. z

Shiling, Dorotheus, 岡本良知訳, 日本における耶蘇会の学校制度, 日本教育史(1943), p.15.

清水義雄，社寺奉納算額集（巻の下），大阪府立中之島図書館蔵(1942), p.325.

\section{References}

Aida, T., Design of the Gears, TAIGA Publishing Co. Ltd. (1971), p1, p.45, p.48 (in Japanese).

Aida, T., The technography of the gears, Kaihatsysya (1970), p.666 (in Japanese).

Aiga, T, Nihon daihyakka zensyu, Syogakukan(1988), p.813 (in Japanese).

Cycloid gear design software manual, AMTEC INC.(2002) (in Japanese).

Fukagawa, H. and Solowsky, D., Japanese 18th and 19th-century mathematical problems 1st edition, Morikita ublishing (1995), p.48 (in Japanese).

Hanawa, H., Ohuchi Yoshitaka-ki, Gunsyo ruijyu, Kan394 (1819), Kassenbu p.26 (in Japanese).

Hirayama, A., The history of $\pi$, Osaka Kyouiku Tosyo (1980), p.280 (in Japanese).

Hoeve , J. and Thompson, D., A fremsh clock at the shogun's shrine antiquarian horology, Vol.35, No.4 (2014), pp.10631076.

Kawakami, M., Influences of conditions of induction heating and quenching on reinforced feature of steel surface layer, Kyoto Institute of Technology graduation thesis (2014), p.11 (in Japanese).

Kawamoto, N., The considering in the period of the beginning of the mechanical watch manufacturing in Japan, Bukkyo University, The Ouyou Historical science, No.39 (2013), pp.149-173 (in Japanese).

Kubota, Y., Mechanism of "Man-nen dokei" a historic perpetual chronometer, Toshiba review Vol.60 No.7(2005), pp.116 - 119 (in Japanese).

Nagoya City, Nagoya history, reprinted edition, Aichi-ken kyoudo siryou kankou-kai (1980), p.159 (in Japanese).

Oda, S., The Japanese traditional clock's picture book, The Seiko Museum (1994), p.5 , p.100(in Japanese).

Okayama Prefectural Museum, Heisei 19year special exhibition 'The shrine of Kibitsu" (2007), p.91 (in Japanese).

Otani, T., About Robertson's " the watch in Japan", Journal of The Wadokei-Gakkai, No.42(2010), p.5 (in Japanese).

Sasaki, K., and Kondo, .K, The Japanese clock made by Sukezaemon Tsuda and Their Characteristics, Journal of The Wadokei-Gakkai, No.42 (2010), pp.16-29 (in Japanese).

Shiling, D. and Okamoto, Y., Society of Jesus's schooling system in Japan, The Japan education history (1943), p.15 (in Japanese).

Shimizu, Y., Syaji hounou sangaku syuu (under the volume), Osaka Prefectural Nakanoshima Library (1942), p.325 (in Japanese). 